\title{
Assessing the impact of modern recharge on a sandstone aquifer beneath a suburb of Doncaster, UK
}

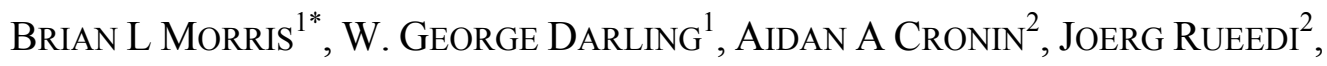 \\ EMILY J WHITEHEAD ${ }^{1}$, DAREN C GOODDY ${ }^{1}$ \\ ${ }^{1}$ British Geological Survey, Maclean Building, Wallingford, Oxon OX10 8BB, UK \\ ${ }^{2}$ Robens Centre for Public \& Environmental Health, University of Surrey, Guildford \\ GU2 7XH, UK \\ *Corresponding author, e-mail blm@bgs.ac.uk, Tel +44-1491-838800, Fax: +44-
}

$1491-692345$

\begin{abstract}
A major water quality issue in urban areas underlain by a productive aquifer is the impact of modern recharge. Using a variety of sample sources including multi-level boreholes, this study has found detectable $\mathrm{CFCs}$ and $\mathrm{SF}_{6}$ throughout the upper $50 \mathrm{~m}$ of the saturated aquifer beneath a suburb of Doncaster, indicating that modern ( $<50$ year old) recharge has penetrated to at least this depth. Additional support for this deep penetration is provided by the detection of sulphite-reducing clostridia and faecal streptococci. Despite the upper aquifer being a poorly cemented sandstone, the residence time indicators suggest that some modern recharge is travelling via fracture systems in addition to that moving down by simple piston flow. However, the overall impact of 80 years of steady urbanisation on water quality in the aquifer beneath this suburb has in general been limited. This is attributed to a combination of factors including previous land use, dilution by direct recharge of rainfall through green-space areas including gardens, and locally high storage in the friable upper aquifer.
\end{abstract}

Key Words: Urban groundwater, $\mathrm{CFCs}_{\mathrm{S}} \mathrm{SF}_{6}$, microbial indicators, PermoTriassic sandstone, groundwater age, urban recharge

\section{Introduction}

A major challenge for water management in cities overlying productive aquifers lies in the complexity of the urban water balance compared with rural catchments (e.g. Lerner et al. 1990, Foster et al. 1994). Losses by leakage from the large volumes of water circulating within the pipe infrastructure (pressurised mains, foul sewers, combined sewers, pluvial drains and sometimes district heating systems), together with percolation from roof runoff/paved area soakaways, provide sources of near-surface recharge additional to those available in rural catchments. At the same time impermeabilisation of the land surface by buildings 
and paved areas changes the scope for local precipitation to enter the aquifer. The resultant intricate mosaic of at-surface and near-surface recharge sources complicates both the quantification of net recharge to the aquifer and the prediction of the effect such recharge may have on groundwater quality (e.g. Eiswirth and Hötzl 1994).

The application of environmental indicators of groundwater residence time has been investigated in and around a suburb of the South Yorkshire town of Doncaster (population c.200,000), which is situated on, and draws its water supply from, a Permo-Triassic sandstone aquifer (Fig.1). The investigation formed part of a larger study that aims to provide and validate (through the medium of city case-studies) a linked array of models that can cope with the complexity of recharge to urban aquifer systems. A wide array of data are being used to inform the chemical and microbiological characterisation of urban shallow aquifer recharge, needed to calibrate the numerical models that together are being used to track water (from precipitation and mains supply) and contaminants (from human activities) through the built environment, to the underlying unsaturated zone and on to the underlying aquifer. (Eiswirth et al. 2002, University of Karlsruhe 2005). Implicit in this approach was the expectation that, in comparison with the rural equivalent, recharge in the urban environment could be characterised by marker species, resulting in a recognisable groundwater 'signature' that would allow the extent and likely effect of urban recharge to be estimated.

\section{Background}

\section{Urban water infrastructure}

The Sherwood Sandstone aquifer, which is the second most important in the UK after the Chalk, is part of a more extensive European Permo-Triassic Bunter and Lower Keuper red-bed sandstone sequence which also forms productive aquifers elsewhere in northwestern Europe. 


\section{Figure 1 Location of Doncaster and Bessacarr-Cantley study area on Permo- Triassic sandstone aquifer}

The study area comprises the Doncaster suburb of Bessacarr-Cantley, located approximately $3 \mathrm{~km}$ southeast of the town centre. The district, with a population of c. 20,000 has urbanised intermittently since the early 1920 s and comprises a mix of residential property and local services (schools with playing fields, retail, community buildings, green space). Town planning controls have kept the district geographically distinct, and both the urban footprint and, as Fig. 2 indicates, its associated water infrastructure of mains supply, wastewater and pluvial drains are well-defined (Morris et al. 2003).

\section{Figure 2 Urban water infrastructure of Bessacarr-Cantley study area and sampling locations}

The piped water supply for the town of Doncaster, its suburbs and surrounding rural area is supplied by the Doncaster wellfield, a linked array of eleven pumping stations extending from just to the east of the town along a $15 \mathrm{~km}$ arc to the northeast and southeast. The $6.3 \mathrm{~km}^{2}$ extent of Bessacarr-Cantley is served by a total length of water bearing pipe infrastructure of almost $220 \mathrm{~km}$, via iron or plastic water mains and vitreous clay or concrete foul sewers and pluvial drainage systems (Rueedi et al. 2004) (Table 1).

\section{Table 1 Pipe infrastructure key statistics for Bessacarr-Cantley}

\section{Geology}

The Permo-Triassic Sherwood Sandstone Group of eastern and northern England outcrops in a structurally controlled arc from south of Nottingham to the North Sea at Hartlepool, Co. Durham. The sandstones in the vicinity of Doncaster have an outcrop width of about $16 \mathrm{~km}$ and dip gently to the ENE at about $1.5^{\circ}$, being 
underlain by low permeability Permian marls and overlain by Triassic mudstones to the east (Figs. 1 and 3).

In South Yorkshire the Sherwood Sandstone has little topographic expression apart from isolated and subdued ridges on its western (basal) margin. The aquifer increases in thickness from its western edge, reaching about $175 \mathrm{~m}$ to the east of Doncaster where the suburbs and nearby former coal mining villages are located. Quaternary superficial deposits ranging from glacial sand-and-gravel to peat and lacustrine silty clays overlie the sandstones in many places and these can exert a major control on recharge processes, flow patterns and solute/contaminant transport (Smedley and Brewerton 1997).

\section{Figure 3 Sketch section across Sherwood Sandstone aquifer in vicinity of Doncaster}

The fluvially deposited Sherwood Sandstone Group comprises a varied series of red and brown, friable to moderately-cemented, well to poorly-sorted and fine to medium-grained sandstones (Gaunt 1994). Thin layers and lenses of mudstone and mud-pellet conglomerates are present in the lowest $40 \mathrm{~m}$ of the aquifer but less common higher in the sequence. Bessacarr-Cantley is underlain either directly by the sandstone aquifer or by intervening permeable Quaternary sands and gravels up to $8 \mathrm{~m}$ thick (Fig. 3). The absence of low-permeability superficial deposits was one criterion in the selection of Bessacarr-Cantley as the study area.

\section{Hydrogeology}

Regional transmissivities of the unconfined Sherwood Sandstone aquifer, derived from pumping tests, lie in the range $100-700 \mathrm{~m}^{2} / \mathrm{d}$ with a median of $207 \mathrm{~m}^{2} / \mathrm{d}$ (Allen et al. 1997). Intergranular porosity measured from core samples is typically around $30 \%$. Specific yield values of around 0.1 are cited from both laboratory measurements and calibrated regional flow models but may be locally an underestimate for the South Yorkshire area due to the poor cementation of the upper part of the saturated aquifer. More locally, permeability tests using inflatable packers in a $59 \mathrm{~m}$ deep borehole (CWT) in Bessacarr gave 
transmissivities of $76 \mathrm{~m}^{2} / \mathrm{d}$ for the upper open-hole zone $(27-41 \mathrm{mbgl})$ and $92 \mathrm{~m}^{2} / \mathrm{d}$ for the lower zone $(41-59 \mathrm{mbgl})$.

Regionally, the Sherwood Sandstone aquifer is considered to be strongly anisotropic as a result both of synsedimentary features (interbedded mud-rich horizons, presence of fining-upwards cycles, channelling) and post-diagenetic structural developments (bedding plane fractures, inclined joints, faults). Intergranular flow is believed to dominate in regional flow systems because fractures are often filled with sand. However, interconnected systems can become well-developed near boreholes as a result of prolonged pumping (Allen et al. 1997). Flow along discontinuities in such areas, especially in the upper $100 \mathrm{~m}$ of the aquifer has been shown to play a significant role in water movement (Price et al. 1982, Jackson and Lloyd 1983, Allen et al. 1997). A recent detailed field study at sites in Nottingham and Birmingham (Taylor et al. 2003), where the Sherwood Sandstone is well-cemented, confirmed that such features exert significant control over the vertical flow component.

Nevertheless, there is evidence that east of Doncaster much of the Sherwood Sandstone aquifer may be less indurated than equivalents elsewhere. Although the lowest $40 \mathrm{~m}$ forms a discontinuous series of low ridges, exposures and core recovery are poor elsewhere (Gaunt 1994) and recent drilling experience in the Bessacarr area has shown much of the upper part of the sandstone sequence to be largely uncemented (Rueedi \& Cronin 2003). This local effect is likely to provide higher storage than the cited regional specific yields suggest. The subdued, near sea-level elevations of most of the Sherwood Sandstone east of Doncaster resulted in wetlands until the early $20^{\text {th }}$ century. This contrasts with further south along the strike of the formation, where the sandstone outcrop is sufficiently well cemented to form relatively high ground e.g. around Nottingham.

The subdued topography around the study area makes assessment of the natural, pre-development flow system speculative. Brown and Rushton (1993) suggest that groundwater would probably have drained from high recharge areas (driftfree or with permeable drift) in the centre and south west of the area, towards the east and north. If so, then Bessacarr-Cantley would historically have comprised a low eminence draining outwards to the $\mathrm{E}, \mathrm{N}$ and $\mathrm{S}$ towards encircling wetlands 
underlain by a full aquifer with very shallow flow systems discharging to local watercourses.

Piezometric data over a 13 month period October 2003 - November 2004 from five multilevel boreholes suggest that vertical hydraulic continuity exists throughout the upper part of the aquifer system. The measurements show that head gradients in the upper $50 \mathrm{~m}$ of the aquifer are very low throughout the study area, typically only a few centimetres, and that the small head differences are maintained in synchronous fashion both during periods of recharge and of recession and at depths to $60 \mathrm{mbgl}$ (Fig. 4).

\section{Figure 4 Piezometric variation in HP2} multilevel. L10, L14 etc refer to depth of sampling port. For comparative purposes the piezometric level in L10 (which fluctuated $0.28 \mathrm{~m}$ over period) has been normalised. Note synchronicity of variation at all ports

\section{down to $60 \mathrm{mbgl}$ and small magnitude of relative head difference}

\section{Environmental indicators}

Any study of the penetration rate of modern recharge in an urban setting demands the most sensitive possible indicators of anthropogenic activity. The atmospheric trace gases $\mathrm{CCl}_{3} \mathrm{~F}$ (CFC-11), $\mathrm{CCl}_{2} \mathrm{~F}$ (CFC-12) and $\mathrm{SF}_{6}$ (sulphur hexafluoride) are increasingly being used as tracers of residence time (Plummer and Busenberg, 1999). Large-scale production of CFC-12 began in the early 1940s, followed in the 1950s by CFC-11. These gases were used for refrigeration and airconditioning, but inevitably leaked into the environment, with atmospheric concentrations rising until the 1990s, when production was cut back to protect the ozone layer, (Fig. 5 left). SF$_{6}$, another industry-derived gas, has been detectable in the atmosphere since the early 1960s and is still rising steadily in concentration 
(Fig 5 left). Unlike tritium, all three of these trace gases are well-mixed in the atmosphere and their input functions are better characterised. When their atmospheric mixing ratios are converted into dissolved concentrations (Fig 5 right), using Henry's Law and known solubilities (Plummer and Busenberg, 1999), these can be compared with concentrations measured in groundwater samples and, assuming no contamination or degradation, the year of recharge can be inferred.

\section{Fig 5 Average atmospheric mixing ratios over time of the CFCs and SF6 in pptv (parts per trillion by volume), and corresponding groundwater concentrations at a recharge temperature of $10^{\circ} \mathrm{C}$. Mixing ratio data from the NOAA (US National Oceanic and Atmospheric Administration).}

The typical routine detection limit for dissolved organics is $1 \mu \mathrm{g} / \mathrm{l}$; CFCs at datable concentrations are several orders of magnitude below this value , making them extremely sensitive indicators of post-1950 recharge. However, this also means that in an urban setting the dating of waters can prove difficult or impossible because input concentrations can be supplemented by local sources of CFCs, possibly venting to the atmosphere (Ho et al, 1998; Santella et al, 2003) or, probably more likely, contaminating the subsurface. Sewage, landfills and industry have all been implicated (Busenberg and Plummer, 1992; Hohener et al, 2002; Morris et al, 2005). $\mathrm{SF}_{6}$ is typically present in groundwaters at concentrations two orders of magnitude below those of the CFCs and can therefore only be measured at lower sensitivity. However, groundwaters are much less susceptible to $\mathrm{SF}_{6}$ contamination (Darling et al, 2005; Morris et al, 2005).

Most major and minor inorganic species are likely to be less sensitive indicators of modern recharge, even in the urban environment. As well as often being 
difficult to quantify the source term, there are also the issues of concentration overlap with natural occurrence in the rock matrix and overlap with diffuse agricultural pollution indicators $\left(\mathrm{Cl}, \mathrm{N}, \mathrm{K}, \mathrm{SO}_{4}\right)$ present from the period prior to urbanisation.

\section{Sampling and analysis}

\section{Locations}

Environmental indicators were sampled at 13 locations in and around the study area (Table 2). Five multilevel research boreholes (36.0 - $60.4 \mathrm{~m}$ deep) were used for depth-specific sampling, while five relatively shallow private wells (30.5 $76.0 \mathrm{~m}$ deep) and three deeper public supply boreholes $(147-168 \mathrm{~m}$ deep) provided depth-integrated samples from open-hole sections or long-screened intervals (Fig. 2).

\section{Table 2 Sampling site description including land use around wellhead}

The multilevel boreholes each comprise a bundled piezometer array of small-bore monitoring wells with $0.30 \mathrm{~m}$ long screens set at various depths, a mediumgrained sand pack being placed in each interval around the centrally located screen port, and with each depth range separated from the adjacent interval by a 1 $-3 \mathrm{~m}$ thick bentonite clay seal. The resultant multilevel boreholes permit saturated zone sampling of up to seven different depths, typically between $10-$ $60 \mathrm{mbgl}$ (Rueedi \& Cronin 2003) (see Fig. 6). The direction and angle of dip of the Sherwood Sandstone means that stratigraphically the five multilevel boreholes are offset in an east-north-easterly direction. Thus, after allowing for elevation differences, boreholes HP1, HP2 and SB penetrate to approximately the same stratigraphic level, but the equivalent horizon would be at 18.3 and $51.6 \mathrm{~m}$ depth respectively in multilevels $\mathrm{BH}$ and MAS. 


\section{Figure 6 Design of 5 multilevel research}

\section{boreholes, Bessacarr-Cantley; thick lines}

indicate steel casing, dark areas the location

of bentonite seals, numbers in bold the

\section{depths of $0.3 \mathrm{~m}$ long sampling port centres}

(from Rueedi and Cronin 2003)

The private wells are poorly documented but available details confirm that these variously abstract mixed waters from within the uppermost $70 \mathrm{~m}$ of saturated aquifer. The public supply boreholes overlap the depth range of both multilevels and private wells, drawing water over long screened sections from $<30$ to $>145 \mathrm{mbgl}$. Samples were taken from dedicated raw water sampling taps in the pumping stations.

\section{Sampling and analysis}

CFC, $\mathrm{SF}_{6}$ and other hydrochemistry: $\mathrm{CFC}$ and $\mathrm{SF}_{6}$ sampling was conducted in autumn 2004. Samples for CFC analysis were collected by the displacement method of Oster (1994), which involves filling a glass bottle and metal can combination under water to avoid atmospheric contact. The glass bottle $(100 \mathrm{ml})$ is flushed with approximately 5 litres of sample water before being stoppered and sealed within the 1-litre can. Samples for $\mathrm{SF}_{6}$ were similarly collected under water, but in 1-litre glass bottles with conically-lined screw caps, according to the method of Busenberg and Plummer (2000). Field measurements of dissolved oxygen (DO), redox potential (Eh), and temperature were measured during sample collection using a flow-through cell connected directly to the wellhead sample tap. Samples for other hydrochemical analysis were taken during sampling campaigns in October 2003 and February, May, and September 2004. These were filtered through $0.45 \mu \mathrm{m}$ cellulose nitrate membranes and collected in pairs of HDPE bottles, one being acidified to $1 \%$ with concentrated Aristar ${ }^{\circledR}$ nitric acid. Samples from the multilevels were taken using either a peristaltic pump or a small-bore 
inertial pump and from the other sites using either the installed pumpset or a sampling pump.

Measurements were made at BGS Wallingford except where stated. CFCs and $\mathrm{SF}_{6}$ were analysed by gas chromatography after pre-concentration by cryogenic methods (Bullister and Weiss, 1988). Cations, $\mathrm{P}$ and $\mathrm{SO}_{4}$ as $\mathrm{S}$ were determined on acidified sample aliquots by ICP-OES. On the unacidified aliquots, nitrogen species and chloride were measured by automated colorimetry. Dissolved organic carbon (DOC) was measured on c. $2 \mathrm{ml}$ of $0.45 \mu \mathrm{m}$ silver membrane-filtered sample. Samples were acidified to approximately $\mathrm{pH} 3$ and sparged with $\mathrm{N}$ gas to remove inorganic carbon prior to thermal oxidation and infra red detection of the evolved carbon dioxide.

Microbiological: Faecal coliforms, total coliforms, faecal streptococci, sulphite reducing clostridia, coliphage, and enteric virus were used as indicators of faecal contamination. These were taken during sampling campaigns in July and November 2003, then in 2004 concurrently with the hydrochemical samples. Bacterial samples were collected directly in sterile bottles and stored in an on-site refrigerator before same-day transport to the laboratory while for thermo-tolerant coliform analysis, filtration and culture was commenced on-site using a portable incubator.

Thermotolerant coliforms (TTC), faecal streptococci (FS) and sulphite reducing clostridia (SRC) were isolated from $100 \mathrm{ml}$ sample volumes using membrane filtration and selectively enumerated by culture on membrane lauryl sulphate broth (TTC), Slanetz and Bartley agar (FS) and perfringens agar (SRC) respectively (Anon. 1994). The results from all analyses were recorded as colony forming units (cfu) per $100 \mathrm{ml}$ (membrane filtration). Enumeration of coliphage was determined by assay of $1 \mathrm{ml}$ of sample using a double agar layer technique (Adams 1959). Two methods were employed for the analysis of enteric viruses (norovirus and enteroviruses) in sample eluates. Buffalo Green Monkey (BGM) kidney cells were used for the quantification of infectious enterovirus by plaque assay, both by the confluent monolayer and suspended cell culture methods (SCA 1995). Results of coliphage and enteric viruses are given as plaque forming units (pfu) per ml. Field blanks and randomly selected duplicates were used as control 
procedures for all sampling rounds at all sites. All field blanks were found to be free of bacterial or viral analytes.

\section{Results}

\section{CFCs and $\mathrm{SF}_{6}$}

All sites. Analyses for $\mathrm{CFCs}_{\text {and }} \mathrm{SF}_{6}$ are given in Table 3. Detectable concentrations of each were found in all cases except for CFC-12 in Nutwell BH2 and one port in one of the multilevel boreholes (45 m in Haslam Park 1), indicating that modern ( $<50$ year old) recharge has penetrated to several tens of metres below ground level. The multilevel boreholes all show a broadly similar distribution of results (Table 3). For the CFCs, this means relatively high concentrations of both CFC-11 and CFC-12 immediately below the water table at $5-10 \mathrm{mbgl}$, followed by a rapid decline towards the region of $40 \mathrm{mbgl}$. Three sites (HP1, HP2, MAS) also show a slight rise again towards the bottom sampler. $\mathrm{SF}_{6}$ concentrations on the other hand tend to show much less variation, though there is generally an overall decrease with depth.

\section{Table $3 \quad$ CFC and $\mathrm{SF}_{6}$ concentrations in Sherwood Sandstone aquifer east of Doncaster}

The private and public water supply boreholes obviously extract waters from a much greater thickness of aquifer than the individual multilevel ports, with the resultant mixing meaning that the high, near-surface concentrations typical of the multilevel boreholes are not generally seen in their discharge except at Cantley Water Tower, where an inflatable packer was able to isolate the zone at $27-41 \mathrm{mbgl}$.

Many of the CFC data exceed the maximum concentrations possible by equilibrium with average atmospheric ratios, and therefore cannot be used to date waters in a quantitative way (Fig. 7A). These are considered further below. The 
other data are plotted in the form of CFC-12 vs $\mathrm{SF}_{6}$ concentration (Fig. 7B). Also shown in Fig. 7B is the curve showing the expected composition of recharge last in contact with the atmosphere at any given time between 1960 and 2005 (atmospheric data from http://water.usgs.gov/lab/cfc/background/air_curve.html), based on an equilibration temperature of $10^{\circ} \mathrm{C}$. In theory this curve can be used to distinguish between piston flow and mixing with old ( $>50$ years) water (Plummer et al. 2001; Darling et al. 2005). It can be seen that rather few samples fall on or near either the piston flow or mixing lines. It has been proposed that urban areas may have atmospheric trace gas excesses (Oster et al. 1996, Ho et al. 1998, Santella et al. 2003), but the present study was unable to confirm this for the Doncaster area. However, about half the sites are reasonably closely associated with the mixing line or zone between the two lines, suggesting that groundwater mixing is an important process at least in this portion of the aquifer. Samples falling well above the mixing line apparently have an $\mathrm{SF}_{6}$ excess; while a significantly higher-than-average excess air value is possibly responsible, it seems more likely to derive from localised contamination since they come from adjacent intervals in a single multilevel $(\mathrm{SB})$ showing above-modern $\mathrm{SF}_{6}$ concentrations in its upper section.

\section{Figure 7A CFC-12 vs $\mathrm{SF}_{6}$ concentrations, all samples. Dashed lines represent water in equilibrium with average 2004 atmospheric concentrations}

\section{Figure 7B CFC-12 vs SF $_{6}$ concentrations; subset of samples showing low or no enrichment from local CFC sources}

Multilevel boreholes. On the evidence of Fig. 7, it appears that mixing between waters is more likely than the previously expected piston flow behaviour. The $\mathrm{CFC}$ and $\mathrm{SF}_{6}$ data from these samples can therefore be converted into 'modern fraction' values, assuming the measured concentrations are the product of mixing 
between modern recharge and $>50$ year old 'dead' water (water containing no $\mathrm{CFCs} / \mathrm{SF}_{6}$ ). The resulting values are plotted vs depth in Fig. 8 .

\section{Figure $8 \quad \mathrm{CFC}, \mathrm{SF}_{6}$ depth plots in 'modern fraction' form}

Four sites show 'over-modern' CFC-11 and CFC-12 fractions (i.e. >1) above 30 mbgl, indicating an element of enrichment from local sources, possibly via sewer leakage (at the fifth site, Sandall Beat, CFC-12 alone shows this trend). With one exception (also Sandall Beat), the equivalent $\mathrm{SF}_{6}$ profiles are much less affected, a feature that is also reported from other urban studies (MacDonald et al. 2003, Darling et al. 2005, Morris et al. 2005); this is attributed to its less widespread use in industry and the residential environment.

A clear feature of all of the profiles is the change to much lower CFC concentrations (and generally lower $\mathrm{SF}_{6}$ ) below $30 \mathrm{~m}$ depth, usually followed by a rise in the deepest sampler. This implies the existence of preferential flow paths, an interpretation supported by the microbiological results.

Ratios of CFC-11 to CFC-12 correlate well for two multilevels (HP1, HP2) and are fairly constant at a third (SB), indicating the importance of mixing/dilution, but are highly variable at the other sites (Fig. 9). A basic interpretation of this pattern is that these latter are either sites where additional sources have appeared over time, or that the catchments of each are much more heterogeneous in terms of additional sources. As the multilevel boreholes have a negligible catchment in the accepted sense (because they are not abstracting boreholes but instead are just intercepting throughflow on its way downgradient), the former interpretation seems the more likely, so that the observed concentrations are the product of several high-CFC sources interacting.

\section{Figure 9 Crossplot of CFC-11 vs CFC-12 for multilevel sites}


Supply boreholes. Table 4 shows the $\mathrm{CFC}$ and $\mathrm{SF}_{6}$ data converted into modern fraction values and, alternatively, year of recharge assuming simple piston flow.

\section{Table $4 \quad$ CFC and $\mathrm{SF}_{6}$ results expressed as modern fraction and as bulk age}

It is clear from Table 4 and Fig. 10 that, like the upper zone of the multilevels, the private boreholes are frequently over-modern in their CFC concentrations, and therefore cannot be used as residence time indicators other than qualitatively, insofar as they indicate widespread penetration of modern water to these boreholes' intake zones. Even the below-modern waters do not agree on grounds of either modern fraction or piston-flow age, suggesting that small amounts of $\mathrm{CFC}$ and/or $\mathrm{SF}_{6}$ are being added from catchment sources.

While there is as yet no evidence, the possibility cannot be wholly discounted of locally higher-than-average atmospheric ratios, perhaps double, although the CFC ratios are not consistent between sites. This has been reported elsewhere (e.g. Oster, 1996) and would have the effect of increasing groundwater ages by up to 20 years

\section{Figure 10 Crossplot of CFC-11 vs CFC-12 for private wells and public supply boreholes in the vicinity of Bessacarr-Cantley}

\section{Hydrochemistry}

Hydrochemical analyses and field measurements representing the HP2 multilevel on four occasions during an 11-month period are given in Table 5 together with selected profiles in Fig. 11. This multilevel provides the most internally consistent record of depth trends in water quality, but its features are also shared to a greater or lesser extent by the other multilevel sites. 


\section{Table 5 Hydrochemical data from HP2 multilevel, including major and selected minor ions and field physicochemical}

measurements

\section{Figure 11 Urban recharge inorganic indicator profiles for HP2, October 2003- September 2004}

The concordance of most of the major ion profiles indicates consistency of results and little or no change between sampling visits. DO values are consistently above $7 \mathrm{mg} / \mathrm{l}$ and often close to saturation at ambient groundwater temperatures of $10-$ $12^{\circ} \mathrm{C}$, while the redox potential (Eh) profiles, although more variable, also illustrate that the upper aquifer is aerobic throughout. Major ion profiles, although they demonstrate clear evidence of stratification, are not consistent in pattern. Several of the recognised inorganic markers of wastewater recharge $\left(\mathrm{K}, \mathrm{SO}_{4}\right.$, $\mathrm{HCO}_{3}$ ) reproduce the $\mathrm{CFC}$ profile pattern referred to earlier, with a change to much lower concentrations below $30 \mathrm{~m}$ and a small rise in the lowermost sampler interval. Similarly, boron content, while low and near detection limit at depth, is demonstrably higher in the upper $30 \mathrm{~m}$. The latter has been recognised elsewhere as a potential sewer leakage indicator in residential areas due to its widespread presence in detergents (Barrett et al. 1999).

However, other commonly employed urban recharge inorganic marker species, such as $\mathrm{Cl}$ and total oxidised nitrogen (TON) show little evidence of significant contaminant loading compared to adjacent rural areas. This lack of contrast is in part a result of low contaminant source concentrations and high 'natural' background levels. This is illustrated in Table 6, which compares the concentration ranges of nine key indicators in various parts of the study area's water infrastructure:

- Bessacarr-Cantley's mains water supply. 
- Foul sewer inspection chambers at outfalls draining the study area.

- The multilevels, with sample intervals categorised into an upper and lower zone.

- Nearby rural/periurban private boreholes/wells.

- Public supply boreholes for which Bessacarr-Cantley forms part of their catchment.

\section{Table 6 Comparison of concentration ranges of potential sewer leakage indicators with those for other parts of urban water infrastructure in Bessacarr-Cantley}

The concentration range of samples from the mainly rural/periurban private and public supply boreholes, is large, at least as great as that found in the multilevel samplers within the urban study area. The reason for the high background levels in the non-urban sites is unknown, but stabilised mine spoil heaps and closed landfill sites are present throughout the area and together these are likely to have had some effect on shallow water quality additional to that which could be expected from agricultural activities. In comparison with indicator concentrations in the rural and periurban waters and incoming mains water, the wastewater loading leaving the district is relatively dilute. For example, for both $\mathrm{Cl}$ and $\mathrm{SO}_{4}$, the additional load is typically only $30-50 \mathrm{mg} / \mathrm{l}$, well within the range of variation in adjacent rural catchments.

The exceptions are the two nutrient sources $\mathrm{N}$ (present as ammonium in wastewater and principally as nitrate in the oxidised environment of the saturated aquifer) and organic $\mathrm{C}$ (measured as DOC). Both appear to be less mobile than other markers, possibly as a result of sequestration in microbial processes occurring in the subsoil in the biologically highly active area around sewer leaks or denitrification to nitrogen gas via nitrite or nitrous oxide. The presence of oxidising conditions in both saturated and unsaturated zone would provide ample opportunity for breakdown of easily degradable organic contaminants. 


\section{Microbiology}

As part of the comparative microbiological study of the study area, several faecal contamination indicators were sampled (Cronin et al. 2005). Table 7 summarises the results.

\section{Table 7 Faecal indicator sampling Jul 2003- Nov 2004(modified from Cronin et al. 2005); results expressed as percentage positives}

Sulphite-reducing clostridia (SRC) has the highest number of positive detects for the regional and multilevel groundwater samples; in fact over $40 \%$ in both cases. SRC are anaerobic spore-forming non-motile bacteria exclusively of faecal origin that can survive in water for longer (months to years) than coliforms or streptococci (generally weeks to months) due to their spore-forming ability (Gleeson and Gray 1997). SRC spores are often found in aerobic systems; while originating in an anaerobic environment, the spores are environmentally hardy and can remain viable in the subsurface for months or longer. The SRC counts include both the non-motile bacteria and the spore stages. Faecal streptococci (FS), an indicator commonly employed both in recreational water monitoring and as a comparison for thermotolerant coliform results, are also detected in $40 \%$ of the multilevel and almost a quarter of regional well analyses.

The results indicate a high positive detects frequency of faecal indicators throughout the upper part of the aquifer. This is striking because in comparison with UK carbonate aquifers like the Chalk or the Jurassic limestones the Sherwood Sandstone is generally regarded as a high-porosity, slow-moving system. However, positive detects of enteric viruses and faecal indicator bacteria have been previously found in similar urban settings in the Sherwood Sandstone underlying Nottingham and Birmingham (Powell et al. 2003), where they have been explained by a small but rapid flow component transporting sewer-derived leakage to depth (Cronin et al. 2003). In this study the counts in the multilevels, although frequent, were universally low. Median values of all parameters were $<1$ and the maximum $90 \%$ percentile values were 11 and $4 \mathrm{cfu} / 100 \mathrm{ml}$ for SRC and 
FS respectively. These results indicate that although positive detects were frequent, the magnitude of these detects was very low, indicating that gross contamination of the groundwater is not evident.

Depth profiles of the two bacterial markers of SRC and FS are shown in Fig. 12 for the multilevel HP2. These gave positive counts in $68 \%$ and $57 \%$ of samples respectively, with positives on one occasion or another at all depth intervals except $35 \mathrm{~m}$. The two faecal indicators results show broadly similar and consistent distributions. These are reminiscent of the $\mathrm{CFC}$ and $\mathrm{SF}_{6}$ profiles in Fig. 7, with higher counts at the shallowest $10 \mathrm{~m}$ and the deepest $60 \mathrm{~m}$ level (in this multilevel, the $10 \mathrm{~m}$ port is $<5 \mathrm{~m}$ below the water table). While there is no evidence of a quality change below $30 \mathrm{~m}$, as demonstrated by the hydrochemical indicators, the intervening depth intervals consistently show low but usually positive counts.

\section{Figure 12 Microbial indicator depth profiles in HP2 multilevel Jul 2003-Sept 2004; 68\% of SRC and $57 \%$ of FS samples gave positive counts}

A temporal evolution (1-2 orders of magnitude) was found in sewage samples from three sampling sites in the project area where maxima were observed in autumn and minima in spring. However the temporal variations of microbial tracers found the groundwater samples are quite small and they do not show a consistent pattern. While a much longer sampling period would be required to draw more detailed conclusions, the consistent presence of low counts of different microbial indicators to several tens of metre depth firmly suggests an element of rapid flow along fracture horizons even under the low vertical head gradients noted earlier.

It is possible to infer a very approximate measure of possible survival time from the results. The removal rate of SRC is difficult to estimate as spores can remain viable in the subsurface for months to years, but published half lives available for 
FS range from 46.2 hours (Yates et al. 1985) to 72.2 hours (Keswick et al. 1982). Measured FS bacterial numbers from sewer sampling in Bessacarr (Cronin et al. 2005) are in the range $10^{5}-10^{6}$ and this organism is not known to reproduce outside an animal host. Table 8 indicates that the time range required for effluent exiting from a sewer leak to decay to FS counts of $<10^{1}$ would be of the order of 25-50 days. As it is highly unlikely that all recharge reaching the multilevel ports is derived from sewer leaks, dilution effects would reduce the decay period, and the implication is that a proportion of the water sampled must be very modern. However, it is important to note that the die-off rates given in Table 8 are typical values and not maximum ones. Several researchers have found survival times for even E. coli cultures in excess of 100 days with some reported survival times up to 5 years in the subsurface (Van Ryneveld and Fourie 1997). Hence, the possibility of longer survival times than those calculated here, and, therefore, longer potential travel times to the sampling intervals cannot be ruled out.

\section{Table 8 Faecal streptococci survivability comparison}

\section{Discussion}

\section{Conceptual groundwater flow model}

In the light of the evidence for large-scale water mixing provided by the environmental indicators used in this study, any groundwater flow model has to explain how recharge is penetrating so rapidly and deeply into a rather poorly consolidated part of the Sherwood Sandstone under conditions of low vertical head difference and negligible local pumping.

Elsewhere the Sherwood Sandstone is observed to behave as a layered aquifer (Jackson and Lloyd 1983, Allen et al. 1997) being generally porous but wellcemented with a variety of minerals including calcite, dolomite, anhydrite and iron oxide. In these sandstones, leakage between strata would occur either via 
cross-layer fractures or require significant head differences in order to counteract the effects of anisotropy (Buckley 2003). In the study area, both the drilling/coring and the seasonal water level response in the multilevel boreholes suggest that bedding plane fractures and other features of a well-cemented sandstone sequence are infrequent throughout much of the uppermost $30 \mathrm{~m}$ of saturated aquifer, so intergranular flow would seem likely to predominate.

A typical intergranular flow rate can be estimated from the mean of the hydraulic conductivity from the packer tests at the Cantley Water Tower borehole CWT $(5.25 \mathrm{~m} / \mathrm{d})$, the local water table gradient of 0.0033 (derived from the sub-regional model representation; Neumann and Hughes 2003) and an effective porosity of 0.1 . This gives a rate of $\sim 63 \mathrm{~m} / \mathrm{a}$. If the upper aquifer were isotropic, a flow rate of this order could quite feasibly allow recharge to penetrate to the $60 \mathrm{~m}$ depths implied by the detection of $\mathrm{CFCs}_{\text {and }} \mathrm{SF}_{6}$, and a mixing-with-modern-water interpretation could explain the concentrations encountered. However it could not explain the microbiological results; intergranular flow rates would be too slow to displace modern recharge to the depths encountered.

Therefore it appears that some mixing must be occurring with modern water moving via fractures in more highly cemented sandstone bands interspersed with the less indurated members. Using the same groundwater gradient and effective porosity values cited above, fracture horizons with a hydraulic conductivity of 30 $-40 \mathrm{~m} / \mathrm{d}$ would theoretically permit a contaminant to pass to the $50-60 \mathrm{~m}$ depths at which the faecal indicators were encountered in 50 days. These are well within the observed range for fissures in the Sherwood Sandstone: Allen et al. 1997 report high transmissivities south of the study area in Nottinghamshire of the order of $1500 \mathrm{~m}^{2} / \mathrm{d}$ of which only $300 \mathrm{~m}^{2} / \mathrm{d}$ may be accounted for by intergranular permeability.

Fractures in the more competent horizons alternating with the less competent sandy strata could provide limited access for modern recharge to penetrate under low head gradient to significant depths. Fig. 13 illustrates the conceptual model, in which the upper $30 \mathrm{~m}$ or so is composed mainly of poorly-cemented strata interspersed with harder fractured horizons. 


\section{Figure 13 Conceptual model of flow system in Sherwood Sandstone in general vicinity of Bessacarr-Cantley suburb of Doncaster}

At depths below $30 \mathrm{~m}$ or so, the scope for mixing with more modern recharge brought down in linked fracture systems is easier to visualise, as depth of burial and increasing cementation produces harder, more structurally competent sandstones in which fracturing can occur more widely. Then the potential for more rapid flow in linked fracture systems would be limited mainly by aperture and the extent of infill of the fractures by sand. In the Doncaster area such structurally-produced discontinuities in the deeper sandstone horizons are likely to be increased by subsidence effects as a result of extensive coal extraction from the underlying Coal Measures (U. Carboniferous). Downhole logging has confirmed the importance of linked fracture systems on flow patterns in the deeper aquifer in water supply boreholes within the Doncaster wellfield, on the margins of which the study area lies (Buckley 2003). It seems reasonable to infer therefore that fracture flow below $30 \mathrm{~m}$ depth is increasingly important, but the effect on apparent age will not be the same throughout: at medium $(30-60 \mathrm{~m})$ depths there is still scope for matrix water to mix with relatively modern water from the surface, whereas with greater depth the fracture-borne water is itself also becoming progressively older and so the bulk age signature increases.

If this conceptualisation is correct, the pattern of the hydrochemical depth profiles does not necessarily imply the slow passage vertically downward of a 'front' of urban recharge. Instead, a given profile could be the product of a complex series of mixing 'cells', slowly evolving as water moves generally downdip (and occasionally cross-dip along discontinuities) into the deeper aquifer. Stratification effects would be the consequence of variable contaminant loadings at the land surface and relative speed of flow.

\section{Water quality implications}

The implications for final water quality in the urban aquifer based on the results presented here are somewhat paradoxical. On the one hand, the $\mathrm{CFC}_{\text {and }} \mathrm{SF}_{6}$ 
environmental tracers and the bacterial indicators show that a component of relatively fast-moving water is entering the aquifer and penetrating to depths of at least $60 \mathrm{~m}$ under modest local pumping influence (from the Doncaster wellfield several kilometres down-gradient). On the other hand, comparison with shallow groundwater from nearby rural/periurban catchments, and from deep public supply boreholes, shows that to date the impact of Bessacarr-Cantley's urbanisation over the last 80 years on both hydrochemical and microbiological water quality appears to be slight, at least for the range of parameters examined in this study. Likely reasons for this are:

A groundwater-benign urbanisation history; Bessacarr-Cantley's development as a sewered residential district with suburban population densities directly replaced a rural landuse. Unlike the more central areas of many cities, there is no 'brownfield' legacy of an intervening period of industry or high-density $19^{\text {th }}$ century housing to leave its contaminant footprint.

(ii) Light contaminant loadings; as Table 6 shows, the predominantly residential land-use, which is relatively low density ( $<35$ persons/ha) is providing a relatively dilute sewage effluent, at least for the inorganic parameters analysed for in this study. This reduces the potential contaminant load from sewer leaks, which are also, given the relatively young age of the housing stock, likely to be less frequent compared with an older inner-city area.

(iii) High aquifer storage capacity; the frequency of consolidated but practically uncemented horizons in the upper part of the saturated aquifer would tend to maximise available storage, providing high dilution potential for recent recharge from water stored in the matrix.

(iv) Availability of dilution from precipitation; the suburban nature of the catchment provides more than $80 \%$ of total area as some form of greenspace (domestic gardens, public parks, school playing fields, verges) and a high proportion of this is able to accept direct recharge from rainfall. An additional indirect contribution would come from those properties where roof runoff is directed to on-site soakaways. 
(v) Further dilution of contamination at the public water supply wells sited downdip: these are usually drilled to at least $125 \mathrm{~m}$ and often have long screened intervals below about $30 \mathrm{mbgl}$. This means that urban contamination, currently observed mainly in the top $30 \mathrm{~m}$ of the aquifer, is significantly diluted by older, uncontaminated water at depth.

The result seems to be an urban recharge system that is relatively resilient in terms of adverse water quality impact, at least in terms of the contaminant indicators used in this study.

\section{Conclusions}

Groundwater has been characterised in a regionally important Permo-Triassic sandstone aquifer beneath a suburb of Doncaster, eastern England in order to assess the nature and effect of urban recharge. A variety of environmental indicators were used to infer the flow regimes of shallow groundwater. The main observations are:

- The anthropogenic compounds CFC-12, CFC-11 and $\mathrm{SF}_{6}$ have been found throughout the upper 50-55 $\mathrm{m}$ of saturated aquifer, indicating that modern $(<50$ year old) recharge has penetrated to many tens of metres below ground level. Excess CFC concentrations at depths of $<30 \mathrm{mbgl}$ indicate local sources of enrichment. In general the evidence suggests the mixing of groundwater rather than piston flow displacement.

- The distribution of microbiological marker species (faecal streptococci and sulphite-reducing clostridia) provides support for this interpretation, in that small positive counts were also consistently detected down to $60 \mathrm{mbgl}$.

- The evidence from standard hydrochemical indicators is less conclusive. While indicators such as $\mathrm{K}, \mathrm{Na}, \mathrm{HCO}_{3}$ and $\mathrm{B}$ were typically elevated at shallow depths, markers that have been successfully used as urban recharge indicators elsewhere, such as $\mathrm{Cl}, \mathrm{SO}_{4}$ and $\mathrm{NO}_{3}$, showed significant variability between sites. Although most sites showed higher solute concentrations in their upper zones, there was no consistent pattern.

- In hydrochemical and microbiological terms, the adverse effect of urban recharge on underlying groundwater quality has been limited, at least in terms of the parameters measured in this study. A number of pollution 
indicator species show little more variation than that encountered in neighbouring rural catchments. This is ascribed to the combined effects of a non-industrial prior land-use history, light contaminant loadings from sewer leakage and urban runoff, locally high storage capacity in the friable upper aquifer and the availability of dilution from precipitation entering green space areas within the urban footprint.

\section{Acknowledgements}

The authors gratefully acknowledge the assistance of our UK project stakeholders Yorkshire Water Plc., the Environment Agency and Doncaster Metropolitan Borough Council with data and discussion. Funding for this project was provided via the UK Natural Environment Research Council and the European Union $5^{\text {th }}$ Framework Directive (Grant \# EVK1-CT-2002-00100). Our colleagues Ilka Neumann and Jenny Cunningham provided helpful comments and data. This paper is published with the permission of the Executive Director, British Geological Survey (NERC).

\section{References}

Adams M H (1959). Bacteriophages. Interscience Publishers, London.

Allen DJ, Brewerton LJ, Coleby LM, Gibbs BR, Lewis MA, Macdonald AM, Wagstaff SJ, Williams AT (1997) The Physical Properties of Major Aquifers in England and Wales. British Geological Survey Technical Report (WD/97/34). Environment Agency R\&D Publication 8, Keyworth UK Anon.(1994). The microbiology of water 1994 Part 1-Drinking water. HMSO, London

Barrett MH, Hiscock KM, Pedley S, Lerner DN, Tellam JH, French MJ (1999) Marker species for identifying urban groundwater recharge sources: a review and case study in Nottingham, UK Water Res 33, 3083-3097

Brown IT, Rushton KR (1993) Modelling of the Doncaster Aquifer. School of Civil Engineering, University of Birmingham, Birmingham

Buckley DK (2003) Pesticides in the Triassic Sandstone aquifer of South Yorkshire:Interpretation of borehole geophysical logging. British Geological Survey Commissioned Report, CF/03/071C

Bullister JL, Weiss RF (1988) Determination of $\mathrm{CCl}_{3} \mathrm{~F}$ and $\mathrm{CCl}_{2} \mathrm{~F}_{2}$ in seawater and air. Deep Sea Res., 35(5), 839-853

Busenberg E, Plummer LN (1992) Use of chlorofluorocarbons $\left(\mathrm{CCl}_{3} \mathrm{~F}\right.$ and $\left.\mathrm{CC}_{2} \mathrm{~F}_{2}\right)$ as hydrologic tracers and age-dating tools: The alluvium and terrace system of central Oklahoma. Water Resour. Res., 28:2257-2283

Busenberg E, Plummer LN (2000) Dating young groundwater with sulfur hexafluoride: natural and anthropogenic sources of sulfur hexafluoride. Water Resour Res 36:3011-3030

Cronin AA, Taylor RG, Powell KL, Barrett MH, Trowsdale SA, Lerner DN (2003) Temporal variations in the depth-specific hydrochemistry and sewage-related microbiology of an urban sandstone aquifer, Nottingham, United Kingdom. Hydrogeol J 11:205-216

Cronin AA, Rueedi J, Morris B L (2005) The effectiveness of selected microbial and chemical indicators to detect sewer elakage impacts on urban groundwater quality. Procs of $10^{\text {th }}$ Int'l Conference on Urban Drainage, Copenhagen, Denmark 21-26 Aug 2005 
Darling WG, Morris BL, Stuart ME, Gooddy DC (2005) Groundwater age indicators from public supplies tapping the Chalk aquifer of Southern England. Water Environ J 19 , 30-40

Eiswirth M, Hötzl H (1994) Groundwater contamination by leaky sewer systems. In Water Down Under, National conference of Institution of Engineeers, Adelaide, Australia 111-114 pp, Nov.1994

Eiswirth M, Hötzl H, Cronin AA, Morris B.L, Veselic M, Bufler R, Burn S, Dillon P (2002) Assessing and improving the sustainability of urban water resources and systems, Proceedings of the Image-Train Cluster Meeting Cracow, Poland. Oct. 2002. Accessible at www.urbanwater.de

Foster SSD, Morris BL, Lawrence AR (1994) Effects of urbanisation on groundwater recharge. In Procs of ICE International Conference on Groundwater Problems in Urban Areas, London, June 1993. Thomas Telford, London

Gaunt GD (1994) Geology of the country around Goole, Doncaster and the Isle of Axholme. British Geological Survey, London

Gleeson C, Gray N (1997). The coliform index and waterborne disease, Problems of microbial drinking water assessment, ISBN 041921870 X, E \& FN Spon Publishers London.

Ho DT, Schlosser P, Smethie Jr. WM, Simpson HJ (1998) Variability in atmospheric chlorofluorocarbons $\left(\mathrm{CCl}_{3} \mathrm{~F}\right.$ and $\left.\mathrm{CCl}_{2} \mathrm{~F}_{2}\right)$ near a large urban area: implications for groundwater dating Environ Sci Technol 32, $2377-2382$

Höhener P, Werner D, Balsiger C, Pasteris G (2002) Occurence and fate of chlorofluorocarbon plumes in groundwater In: S.F. Thornton and S.E. Oswald (Eds) 'Groundwater Quality: Natural and Enhanced Restoration of Groundwater Pollution' IAHS Publ. No. 275, 41-47

Jackson D, Lloyd JW (1983) Groundwater chemistry of the Birmingham Triassic Sandstone aquifer and its relation to structure. Q J EngGeol 16, 135-142

Keswick BH, Wang D, Gerba CP (1982) The use of microorganisms as groundwater tracers. Groundwater 20, 142-149.

Lerner DN, Issar SI., Simmers I (1990) Recharge due to Urbanisation, from 'Groundwater Recharge, A guide to understandingand estimating natural recharge'. International Contributions to Hydrogeology Vol 8, IAH Publications Verlag Heinz Heise, Hannover

MacDonald AM, Darling WG, Ball DF, Oster H (2003) Identifying trends in groundwater using residence time indicators: an example from the Permian aquifer of Dumfries, Scotland. Hydrogeol J 11, 504-517

Morris BL, Stuart ME, Cronin AA (2003) Assessing and Improving Sustainability of Urban Water Resources and Systems: AISUWRS Work-package 1 Background study. CR/03/052C, British Geological Survey, Keyworth, Nottingham

Morris BL, Darling WG, Gooddy DC, Litvak RG, Neumann I., Nemaltseva EJ, Poddubnaia I (2005) Assessing the extent of induced leakage to an urban aquifer using environmental tracers: an example from Kyrgyzstan, Central Asia. Hydrogeol J On-Line DOI 10.1007/s10040-005-0441-x

Neumann I, Hughes A (2003) Translation of the Doncaster Groundwater Model into the MODFLOW code. British Geological Survey Commissioned Report, CR/03/258N. 27 pp

Oster, H. (1994): Datierung von Grundwasser mittels FCKW: Voraussetzungen,Möglichkeiten und Grenzen.Dissertation, Universität Heidelberg.

Oster H, Sonntag C, Munnich KO (1996) Groundwater age dating with chlorofluorocarbons. Water Resour Res 37, 2989

Powell KL, Taylor RG, Cronin AA, Barrett MH, Pedley S, Sellwood J, Trowsdale S, Lerner DN. (2003) Microbial contamination of two urban sandstone aquifers in the UK, Water Res 37, 339-352.

Plummer LN, Busenberg E. Chlorofluorocarbons. 1999. In: Cook PG, Herczeg AL (eds) Environmental tracers in subsurface hydrology. pp 441-478, Kluwer, Dordrecht

Plummer LN, Busenberg E, Bohlke JK, Nelms DL, Michel RL, Schlosser P (2001) Groundwater residence times in Shenandoah National Park, Blue Ridge Mountains, Virginia, USA: a multi-tracer approach Chem Geol 179, 93-111

Price M, Morris B, Robertson A (1982) A study of intergranular and fissure permeability in Chalk and Permian aquifers, using double-packer injection testing. J Hydrol 54, 410-423

Rueedi J, Cronin AA (2003) Construction of 5 Depth Specific Groundwater Sampling Sites in Doncaster, UK. Robens Centre for Public and Environmental Health, Guildford

Rueedi J, Cronin AA, Morris BL (2004) AISUWRS Work-package 4: Field investigations interim report. British Geological Survey Commissioned Report, CR/04/022N 72 pp 
Santella RM, Ho DT, Schlosser P, Stute M (2003) The distribution of atmospheric SF6 near a large urban area as recorded in the vadose zone. Envir Sci Technol 37, 1069-1074

Standing Committee of Analysts (SCA) (1995). Methods for the isolation and identification of human enteric viruses from waters and associated materials. Methods for the examination of waters and associated materials. HMSO, London.

Smedley PL, Brewerton LJ (1997) The natural (baseline) quality of groundwater in England and Wales. Part 2: the Triassic Sherwood Sandstone of the East Midlands and South Yorkshire. British Geological Survey Technical Report WD/97/52. BGS Keyworth England

Taylor RG, Cronin AA, Trowsdale SO, Baines OP, Barrett MH, Lerner DN (2003) Vertical groundwater flow in Permo-Triassic sediments underlying two cities in the Trent River Basin (UK). J Hydrol 284:92-113

University of Karlsruhe, Dept of Applied Geology. AISUWRS- Assessing and Improving the Sustainability of Urban Water Resources and Systems, Website http://www.urbanwater.de

VanRyneveld MB, Fourie AB (1997). A strategy for evaluating the environmental impact of on-site sanitation systems. Water SA 23: 279-291

Wilson GB, Andrews JN, Bath AH (1994) The nitrogen isotope composition of groundwater nitrates from the East Midlands Triassic Sandstone aquifer, England. J Hydrol 157:35-46

Yates, M. V., Gerba, C. P., \& Kelley, L. M. (1985). Virus persistence in groundwater. Appl Environ Microbiol. 49, 778-781 


\section{List of Tables}

Table $1 \quad$ Pipe infrastructure key statistics for Bessacarr-Cantley

Table $2 \quad$ Sampling site description including land use around wellhead

Table $3 \quad \mathrm{CFC}$ and $\mathrm{SF}_{6}$ concentrations in Sherwood Sandstone aquifer east of Doncaster

Table $4 \quad$ CFC and $\mathrm{SF}_{6}$ results expressed as modern fraction and as bulk age

Table 5 Hydrochemical data from HP2 multilevel, including major and selected minor ions and field physicochemical measurements.

Table 6 Comparison of concentration ranges of potential sewer leakage indicators with those for other parts of urban water infrastructure in Bessacarr-Cantley

Table 7 Faecal indicator sampling Jul 2003- Nov 2004(modified from Cronin et al 2005); results expressed as percentage positives

Table $8 \quad$ Faecal streptococci survivability comparison 


\begin{tabular}{lccl}
\hline \multicolumn{1}{c}{ Pipe network type } & Pipe asset count & Total length $(\mathrm{km})$ & Materials comments \\
\hline Mains supply & 1135 & 91.6 & $84 \%$ by length cast or ductile iron, $15 \%$ PVC/PE \\
Sewer-foul \& combined & 1205 & 56.9 & $87 \%$ by length vitrified clay, $12 \%$ concrete \\
Drain-pluvial (stormwater) & 1413 & 71.1 & $47 \%$ by length vitrified clay, 53\% concrete \\
Totals & 3753 & 219.6 & \\
\hline
\end{tabular}


Table 2 Sampling site description including land use around wellhead

\begin{tabular}{|c|c|c|c|c|c|}
\hline $\begin{array}{l}\text { Site } \\
\text { Ref }\end{array}$ & Site type & Site Name & Tot.depth (m) & $\begin{array}{l}\text { Depth to screen top } \\
\text { or sampling port }\end{array}$ & Land use at wellhead \\
\hline 1 & $\begin{array}{l}\text { Multilevel } \\
\text { research b/h }\end{array}$ & Sandall Beat & 36.0 & $\begin{array}{l}15.6,21.0,26.0,31.0 \\
36.0\end{array}$ & $\begin{array}{l}\text { Grassed public playing field downgradient of } \\
1930 \text { s housing estate }\end{array}$ \\
\hline 2 & $\begin{array}{l}\text { Multilevel } \\
\text { research b/h }\end{array}$ & Haslam Park 1 & 60.1 & $\begin{array}{l}10.0,14.5,21.0,28.0 \\
35.0,45.0,60.1\end{array}$ & $\begin{array}{l}\text { Public garden surrounded by } 1919-1970 \\
\text { substantial detached houses with gardens }\end{array}$ \\
\hline 3 & $\begin{array}{l}\text { Multilevel } \\
\text { research b/h }\end{array}$ & Haslam Park 2 & 60.4 & $\begin{array}{l}9.5,14.0,19.0,27.0 \\
35.0,45.0,60.4\end{array}$ & $\begin{array}{l}\text { Public garden surrounded by } 1919-1970 \\
\text { substantial detached houses with gardens }\end{array}$ \\
\hline 4 & $\begin{array}{l}\text { Multilevel } \\
\text { research b/h }\end{array}$ & Bolton Hill & 51.4 & $\begin{array}{l}16.6,22.2,28.7 \\
34.7,39.7,45.7,51.4\end{array}$ & $\begin{array}{l}\text { Grassed public playing field surrounded by } \\
\text { mixed detached houses with gardens }\end{array}$ \\
\hline 5 & $\begin{array}{l}\text { Multilevel } \\
\text { research b/h }\end{array}$ & $\begin{array}{l}\text { McAuley } \\
\text { School }\end{array}$ & 60.1 & $\begin{array}{l}9.5,21.0,28.0,35.0 \\
45.0,60.1\end{array}$ & $\begin{array}{l}\text { School playing field surrounded by open land or } \\
\text { school buildings }\end{array}$ \\
\hline 6 & $\begin{array}{l}\text { Private water } \\
\text { supply } \mathrm{b} / \mathrm{h}\end{array}$ & $\begin{array}{l}\text { Doncaster } \\
\text { Racecourse }\end{array}$ & 41.1 & $\mathrm{NA}$ & Grass parkland \\
\hline 7 & $\begin{array}{l}\text { Private water } \\
\text { supply well }\end{array}$ & Pegler Ltd & 30.5 & 5.2 & $\begin{array}{l}\text { Brass foundry and factory in mixed industrial } \\
\text { and } 19^{\text {th }} / 20^{\text {th }} \text { century inner city }\end{array}$ \\
\hline 8 & $\begin{array}{l}\text { Observation } \\
\mathrm{b} / \mathrm{h}\end{array}$ & $\begin{array}{l}\text { Cantley Water } \\
\text { Tower }\end{array}$ & 58.9 & 27.2 & $\begin{array}{l}\text { Grassed property enclosed by detached /semi- } \\
\text { det./terraced post- } 1950 \text { housing }\end{array}$ \\
\hline 9 & $\begin{array}{l}\text { Observation } \\
\mathrm{b} / \mathrm{h}\end{array}$ & $\begin{array}{l}\text { Warning } \\
\text { Tongue Lane }\end{array}$ & 63.4 & 18.3 & $\begin{array}{l}\text { Paddock on rural outer edge of post- } 1980 \\
\text { housing }\end{array}$ \\
\hline 10 & $\begin{array}{l}\text { Private water } \\
\text { supply b/h }\end{array}$ & $\begin{array}{l}\text { Gatewood } \\
\text { Grange }\end{array}$ & 76.2 & NA & Rural property \\
\hline 11 & $\begin{array}{l}\text { Public water } \\
\text { supply b/h }\end{array}$ & Nutwell PS & 152.4 & 33.0 & $\begin{array}{l}\text { Periurban multi-borehole complex, rural in } \\
\text { immediate vicinity }\end{array}$ \\
\hline 12 & $\begin{array}{l}\text { Public water } \\
\text { supply b/h }\end{array}$ & Armthorpe PS & 167.6 & 30.5 & $\begin{array}{l}\text { Periurban multi-borehole complex, rural in } \\
\text { immediate vicinity }\end{array}$ \\
\hline 13 & $\begin{array}{l}\text { Public water } \\
\text { supply b/h }\end{array}$ & $\begin{array}{l}\text { Rossington } \\
\text { Bridge PS }\end{array}$ & 147.0 & 28.8 & $\begin{array}{l}\text { Periurban multi-borehole complex, large } \\
\text { suburban properties in immediate vicinity }\end{array}$ \\
\hline
\end{tabular}

$\mathrm{b} / \mathrm{h}=$ borehole $-\mathrm{PS}=$ Pumping station 
Table $3 \mathrm{CFC}$ and $\mathrm{SF}_{6}$ concentrations in Sherwood Sandstone aquifer east of Doncaster

\begin{tabular}{|c|c|c|c|c|c|c|c|c|}
\hline Sample location & Type & $\begin{array}{l}\text { *Depth } \\
\text { (m) }\end{array}$ & $\begin{array}{c}\mathrm{CFC}- \\
12 \\
\mathrm{pmol} / \mathrm{L}\end{array}$ & \pm & $\begin{array}{c}\text { CFC- } \\
11 \\
\mathrm{pmol} / \mathrm{L}\end{array}$ & \pm & $\begin{array}{c}\mathrm{SF}_{6} \\
\mathrm{fmol} / \mathrm{L}\end{array}$ & \pm \\
\hline \multirow[t]{7}{*}{ Haslam Pk 1} & $\mathrm{M} / \mathrm{l}$ & 10 & 5.50 & 0.14 & 12.77 & 0.32 & 1.88 & 0.19 \\
\hline & $\mathrm{M} / 1$ & 14 & 4.86 & 0.12 & 11.90 & 0.30 & 1.39 & 0.14 \\
\hline & $\mathrm{M} / \mathrm{l}$ & 21 & 4.37 & 0.11 & 10.48 & 0.26 & 1.06 & 0.11 \\
\hline & $\mathrm{M} / 1$ & 28 & 2.14 & 0.05 & 5.23 & 0.13 & 1.30 & 0.13 \\
\hline & $\mathrm{M} / 1$ & 35 & 0.09 & 0.00 & 0.90 & 0.02 & 1.04 & 0.10 \\
\hline & $\mathrm{M} / 1$ & 45 & $<0.02$ & - & 0.47 & 0.01 & 0.81 & 0.08 \\
\hline & $\mathrm{M} / \mathrm{l}$ & 60 & 2.63 & 0.07 & 6.44 & 0.16 & 1.09 & 0.11 \\
\hline \multirow{7}{*}{ Haslam Pk 2} & $\mathrm{M} / 1$ & 10 & 3.06 & 0.08 & 8.33 & 0.21 & 2.33 & 0.23 \\
\hline & $\mathrm{M} / 1$ & 14 & 4.12 & 0.10 & 14.93 & 0.37 & 0.91 & 0.09 \\
\hline & $\mathrm{M} / \mathrm{l}$ & 19 & 4.20 & 0.11 & 15.42 & 0.39 & 1.62 & 0.16 \\
\hline & $\mathrm{M} / 1$ & 27 & 3.43 & 0.09 & 12.72 & 0.32 & 1.78 & 0.18 \\
\hline & $\mathrm{M} / 1$ & 35 & 0.14 & 0.00 & 0.50 & 0.01 & 0.67 & 0.07 \\
\hline & $\mathrm{M} / 1$ & 45 & 0.05 & 0.00 & 0.40 & 0.01 & 0.89 & 0.09 \\
\hline & $\mathrm{M} / 1$ & 60 & 1.02 & 0.03 & 3.66 & 0.09 & 0.81 & 0.08 \\
\hline \multirow[t]{7}{*}{ Bolton Hill } & $\mathrm{M} / 1$ & 16 & 5.12 & 0.13 & 13.94 & 0.35 & 1.06 & 0.11 \\
\hline & $\mathrm{M} / 1$ & 22 & 4.85 & 0.12 & 12.98 & 0.32 & 0.97 & 0.10 \\
\hline & $\mathrm{M} / 1$ & 28 & 3.58 & 0.09 & 8.69 & 0.22 & 0.61 & 0.06 \\
\hline & $\mathrm{M} / 1$ & 34 & 3.53 & 0.09 & 1.74 & 0.04 & 0.85 & 0.09 \\
\hline & $\mathrm{M} / 1$ & 39 & 3.68 & 0.09 & 2.06 & 0.05 & 0.67 & 0.07 \\
\hline & $\mathrm{M} / 1$ & 45 & 0.33 & 0.01 & 1.47 & 0.04 & 0.80 & 0.08 \\
\hline & $\mathrm{M} / 1$ & 51 & 1.57 & 0.04 & 0.77 & 0.02 & & \\
\hline \multirow[t]{5}{*}{ Sandall Beat } & $\mathrm{M} / \mathrm{l}$ & 16 & 4.25 & 0.11 & 2.65 & 0.07 & 3.98 & 0.40 \\
\hline & $\mathrm{M} / 1$ & 21 & 5.43 & 0.14 & 2.90 & 0.07 & 3.58 & 0.36 \\
\hline & $\mathrm{M} / 1$ & 26 & 5.29 & 0.13 & 2.35 & 0.06 & 3.61 & 0.36 \\
\hline & $\mathrm{M} / 1$ & 31 & 1.32 & 0.03 & 0.34 & 0.01 & 2.00 & 0.20 \\
\hline & $\mathrm{M} / \mathrm{l}$ & 36 & 2.20 & 0.05 & 2.63 & 0.07 & 2.24 & 0.22 \\
\hline MacAuley & $\mathrm{M} / 1$ & 9 & 19.20 & 0.48 & 9.83 & 0.25 & 2.61 & 0.26 \\
\hline \multirow[t]{6}{*}{ School } & $\mathrm{M} / \mathrm{l}$ & 14 & 10.34 & 0.26 & 11.84 & 0.30 & 1.55 & 0.15 \\
\hline & $\mathrm{M} / 1$ & 21 & 12.21 & 0.31 & 12.12 & 0.30 & 2.12 & 0.21 \\
\hline & $\mathrm{M} / 1$ & 28 & 4.78 & 0.12 & 26.69 & 0.67 & 1.25 & 0.13 \\
\hline & $\mathrm{M} / 1$ & 36 & 4.19 & 0.10 & 8.43 & 0.21 & 4.28 & 0.43 \\
\hline & $\mathrm{M} / \mathrm{l}$ & 45 & 0.13 & 0.00 & 1.00 & 0.02 & 0.28 & 0.03 \\
\hline & $\mathrm{M} / 1$ & 60 & 0.62 & 0.02 & 1.27 & 0.03 & 0.72 & 0.07 \\
\hline Racecourse & PrW & 41 & 4.00 & 0.10 & 3.81 & 0.10 & & \\
\hline Pegler Ltd & PrW & 31 & 0.58 & 0.01 & 1.79 & 0.04 & 1.15 & 0.12 \\
\hline Cantley WT & PrW & 59 & 5.35 & 0.13 & 12.45 & 0.31 & 0.82 & 0.08 \\
\hline Open hole & & & & & & & & \\
\hline $\begin{array}{l}\text { Cantley WT UZ } \\
27-41 \mathrm{~m}\end{array}$ & PrW & 41 & 4.76 & 0.12 & 9.03 & 0.23 & 1.19 & 0.12 \\
\hline $\begin{array}{l}\text { Cantley WT LZ } \\
41-59 \mathrm{~m}\end{array}$ & PrW & 59 & 4.25 & 0.11 & 7.80 & 0.19 & 1.35 & 0.14 \\
\hline $\begin{array}{l}\text { Warning } \\
\text { Tongue Lane }\end{array}$ & PrW & 63 & 3.64 & 0.09 & 13.81 & 0.35 & 1.82 & 0.18 \\
\hline $\begin{array}{l}\text { Gatewood } \\
\text { Grange }\end{array}$ & PrW & 76 & 1.13 & 0.03 & 0.22 & 0.01 & 0.36 & 0.04 \\
\hline $\begin{array}{l}\text { Nutwell PS- } \\
\text { BH2 }\end{array}$ & PWS & 152 & $<0.02$ & - & 0.75 & 0.02 & 0.31 & 0.03 \\
\hline Armthorpe PS & PWS & 168 & 1.46 & 0.04 & 6.85 & 0.17 & 1.03 & 0.10 \\
\hline $\begin{array}{l}\text { Rossington Br. } \\
\text { PS-BH } 1\end{array}$ & PWS & 147 & 0.45 & 0.01 & 1.76 & 0.04 & 0.97 & 0.10 \\
\hline
\end{tabular}

$\mathrm{M} / \mathrm{l}=$ multilevel, $\mathrm{PrW}=$ Private well, PWS = public water supply, UZ,LZ = Upper, Lower zone

A blanket correction factor of 0.75 has been applied to measured $\mathrm{SF}_{6}$ concentrations to account for the presence of 'excess air', based on $\mathrm{N}_{2} /$ Ar measurements made by Wilson et al. (1994) in the Sherwood Sandstone north of Nottingham. 
Table $4 \quad \mathrm{CFC}$ and $\mathrm{SF}_{6}$ results expressed as modern fraction and as bulk age; a modern fraction value of $>1$ signifies a local source additional to average atmospheric ratios

\begin{tabular}{|c|c|c|c|c|c|c|c|c|}
\hline $\begin{array}{l}\text { Sample } \\
\text { location }\end{array}$ & Type & $\begin{array}{l}\text { *Depth } \\
\text { (m) }\end{array}$ & $\begin{array}{l}\text { CFC-12 } \\
\text { Modern } \\
\text { Fraction }\end{array}$ & $\begin{array}{l}\text { CFC-11 } \\
\text { Modern } \\
\text { Fraction }\end{array}$ & $\begin{array}{c}\mathrm{SF}_{6} \\
\text { Modern } \\
\text { fraction }\end{array}$ & $\begin{array}{l}\text { CFC-12 } \\
\text { Bulk age }\end{array}$ & $\begin{array}{l}\text { CFC-11 } \\
\text { Bulk age }\end{array}$ & $\begin{array}{c}\mathrm{SF}_{6} \\
\text { Bulk } \\
\text { age }\end{array}$ \\
\hline $\begin{array}{l}\text { Doncaster } \\
\text { Racecourse }\end{array}$ & PrW & 41 & 1.35 & 0.68 & & $>$ modern & 1981 & \\
\hline Pegler Ltd & PrW & 31 & 0.19 & 0.32 & 0.50 & 1969 & 1973 & 1992 \\
\hline $\begin{array}{l}\text { Cantley WT } \\
\text { Open hole }\end{array}$ & PrW & 59 & 1.81 & 2.21 & 0.35 & $>$ modern & $>$ modern & 1988 \\
\hline $\begin{array}{l}\text { Cantley WT } \\
\text { Upper Zone }\end{array}$ & PrW & 41 & 1.60 & 1.67 & 0.51 & $>$ modern & $>$ modern & 1993 \\
\hline $\begin{array}{l}\text { Cantley WT } \\
\text { Lower Zone }\end{array}$ & PrW & 59 & 1.43 & 1.44 & 0.58 & $>$ modern & $>$ modern & 1994 \\
\hline $\begin{array}{l}\text { Warning } \\
\text { Tongue Lane }\end{array}$ & PrW & 63 & 1.23 & 2.45 & 0.78 & $>$ modern & $>$ modern & 1999 \\
\hline $\begin{array}{l}\text { Gatewood } \\
\text { Grange Farm }\end{array}$ & PrW & 76 & 0.38 & 0.04 & 0.15 & 1974 & 1960 & 1980 \\
\hline $\begin{array}{l}\text { Nutwell PS } \\
\text { BH2 }\end{array}$ & PWS & 152 & 0.00 & 0.13 & 0.13 & $<1948$ & 1967 & 1979 \\
\hline $\begin{array}{l}\text { Armthorpe } \\
\text { PS (fm } \\
\text { Nutwell) }\end{array}$ & PWS & 168 & 0.49 & 1.21 & 0.44 & 1977 & $>$ modern & 1991 \\
\hline $\begin{array}{l}\text { Rossington } \\
\text { Br. PS BH } 1\end{array}$ & PWS & 147 & 0.15 & 0.33 & 0.42 & 1967 & 1972 & 1990 \\
\hline
\end{tabular}

* Recorded depth of borehole or in case of Cantley WT, to base of packer test zone 
Table 5 Hydrochemical data from HP2 multilevel, including major and selected minor ions and field physicochemical measurements

\begin{tabular}{|c|c|c|c|c|c|c|c|c|c|c|c|c|c|c|c|c|c|c|c|c|c|}
\hline \multirow{3}{*}{\multicolumn{2}{|c|}{$\begin{array}{c}\text { Depth } \\
\text { interval } \\
(\mathrm{m}) 0\end{array}$}} & \multicolumn{8}{|c|}{ Major ions } & \multicolumn{7}{|c|}{ Minor ions } & \multicolumn{5}{|c|}{ Field measurements } \\
\hline & & $\begin{array}{c}\mathrm{Ca} \\
\mathrm{mg} / 1\end{array}$ & $\begin{array}{c}\mathrm{Mg} \\
\mathrm{mg} / 1\end{array}$ & $\begin{array}{c}\mathrm{Na} \\
\mathrm{mg} / \mathrm{l}\end{array}$ & $\begin{array}{c}\mathrm{K} \\
\mathrm{mg} / \mathrm{l}\end{array}$ & $\begin{array}{c}\mathrm{HCO}_{3} \\
\mathrm{mg} / \mathrm{l}\end{array}$ & $\begin{array}{c}\mathrm{Cl} \\
\mathrm{mg} / \mathrm{l}\end{array}$ & $\begin{array}{c}\mathrm{SO}_{4} \\
\mathrm{mg} / 1\end{array}$ & $\begin{array}{l}\mathrm{TON} \\
\mathrm{mg} / \mathrm{l}\end{array}$ & $\begin{array}{c}\mathrm{Al} \\
\mu \mathrm{g} / 1\end{array}$ & $\begin{array}{c}\mathrm{B}^{1} \\
\mu \mathrm{g} / \mathrm{l}\end{array}$ & $\begin{array}{c}\mathrm{B}^{2} \\
\mu \mathrm{g} / 1\end{array}$ & $\begin{array}{l}\mathrm{DOC} \\
\mathrm{mg} / \mathrm{l}\end{array}$ & $\begin{array}{c}\mathrm{Fe} \\
\mu \mathrm{g} / 1\end{array}$ & $\begin{array}{l}\mathrm{Mn} \\
\mu \mathrm{g} / 1\end{array}$ & $\begin{array}{c}\mathrm{P} \\
\mu \mathrm{g} / 1\end{array}$ & $\begin{array}{c}\text { SEC } \\
\mu \mathrm{S} / \mathrm{cm}\end{array}$ & $\begin{array}{c}\text { Temp } \\
{ }^{\circ} \mathrm{C}\end{array}$ & $\begin{array}{l}\mathrm{DO}_{2} \\
\mathrm{mg} / \mathrm{l}\end{array}$ & $\begin{array}{l}\text { Eh } \\
\mathrm{mV}\end{array}$ & $\mathrm{pH}$ \\
\hline & & 36.5 & 16.3 & 7.03 & 3.09 & 75 & 10.8 & 41.3 & 11 & 961 & $<80$ & & & 697 & 33.5 & 110 & & 11.6 & 7.08 & 382 & 6.9 \\
\hline \multirow{7}{*}{$\begin{array}{l}0 \\
0 \\
0 \\
0\end{array}$} & 14 & 43.3 & 18.8 & 8.49 & 3.93 & 86 & 16.8 & 59.4 & 9.69 & 56.8 & 100 & & & 1.52 & 15.1 & 112 & & 11.7 & & 362 & 7.52 \\
\hline & 19 & 49.1 & 19.9 & 9.49 & 4.44 & 88 & 20 & 66.7 & 8.67 & 75.2 & $<80$ & & & 6.35 & 10.1 & 159 & & 11.4 & 7 & 383 & 7.03 \\
\hline & 27 & 43.1 & 18.5 & 8.51 & 3.78 & & 16.4 & 57 & 9.71 & 178 & $<80$ & & & 29.9 & 9.19 & 202 & & 11.7 & 6.66 & 378 & 6.82 \\
\hline & 35 & 35.4 & 11.8 & 10 & 1.98 & 30 & 29.2 & 49.5 & 10.4 & 703 & $<80$ & & & 133 & 12.7 & 162 & & 11.5 & 7.85 & 383 & 6.84 \\
\hline & 45 & 24.4 & 8.95 & 6.72 & 1.29 & 30 & 17.4 & 23.3 & 9.49 & 1030 & $<80$ & & & 206 & 6.54 & 172 & & 11.5 & 7.69 & 374 & 7.22 \\
\hline & 60 & 23.7 & 7.56 & 10.8 & 1.45 & 53 & 12.1 & 11.5 & 7.66 & 776 & $<80$ & & & 162 & 10.7 & 184 & & 11.2 & 8.25 & 369 & 7.31 \\
\hline & 10 & 32.2 & 15.1 & 7.61 & 6.29 & 93 & 9.8 & 39.2 & 8.93 & 222 & 84 & & & 320 & 18.4 & 119 & 409 & & 5.59 & & 7.83 \\
\hline \multirow{6}{*}{$\begin{array}{l}0 \\
0 \\
0 \\
0\end{array}$} & 14 & 48.5 & 21 & 9.85 & 5.06 & 82 & 20.8 & 65.6 & 9.35 & 33.2 & 92 & & & 4.01 & 7.53 & 146 & 516 & 11.3 & 5.5 & 452 & 7.8 \\
\hline & 19 & 47.7 & 19.5 & 8.94 & 4.92 & 88 & 20.5 & 62.7 & 8.39 & 33.2 & 80 & & & 4.8 & 6.53 & 164 & 507 & 10.9 & 6.02 & 434 & 7.72 \\
\hline & 27 & 46.3 & 19.2 & 8.84 & 4.58 & 90 & 19 & 60.8 & 9.41 & 62.5 & 63 & & & 12.3 & 6.56 & 226 & 488 & 11 & 4.95 & 430 & 7.63 \\
\hline & 35 & 36 & 12.5 & 8.77 & 2.12 & 27 & 33.8 & 47.1 & 10.7 & 77.1 & $<50$ & & & 14 & 6.5 & 195 & 412 & 10.7 & 6.75 & 437 & 7.59 \\
\hline & 45 & 25.8 & 9.53 & 6.42 & 1.34 & 28 & 18 & 24.3 & 9.42 & 154 & $<50$ & & & 28 & 3.74 & 199 & 290 & 10.7 & 7.49 & 426 & 7.52 \\
\hline & 60 & 28.7 & 10.7 & 7.54 & 1.91 & 70 & 14.7 & 23.2 & 8.58 & 294 & 64 & & & 67 & 6.6 & 255 & 312 & 10.1 & 6.26 & 414 & 8.18 \\
\hline \multirow{7}{*}{$\begin{array}{l}\text { J } \\
\text { ¿ } \\
\sum\end{array}$} & 10 & 31.8 & 15 & 5.69 & 5.23 & 111 & 10.7 & 35.7 & 9.07 & 110 & 88 & 61 & & 44.5 & 22.6 & 28 & 319 & 10.8 & 8.84 & 371 & 7.81 \\
\hline & 14 & 47.4 & 20.2 & 9.83 & 4.87 & 119 & 25.1 & 60.8 & 8.32 & 350 & 66 & 86 & & 103 & 3.5 & 80 & 418 & 10.7 & 10.8 & 350 & 8.04 \\
\hline & 19 & 48.3 & 19.9 & 8.98 & 5.11 & 124 & 24.7 & 60.8 & 8.16 & 44.5 & 98 & 62 & & 8.36 & 3.3 & 112 & 500 & 11 & 8.4 & 357 & 7.91 \\
\hline & 27 & 47.5 & 19.9 & 8.81 & 4.72 & 127 & 23 & 59.1 & 9.3 & 789 & 60 & 62 & & 259 & 4.92 & 162 & 484 & 10.9 & 7.32 & 382 & 7.53 \\
\hline & 35 & 35.3 & 12.6 & 9 & 2.16 & 24 & 36.1 & 45.3 & 10.6 & 459 & 31 & $<20$ & & 94.6 & 4.21 & 168 & 403 & 10.8 & 8.89 & 346 & 7.65 \\
\hline & 45 & 24.4 & 9.09 & 6.29 & 1.27 & 24 & 20 & 22.7 & 9.28 & 175 & $<30$ & $<20$ & & 35.2 & 2.42 & 150 & 280 & 11.2 & 9.43 & 354 & 7.7 \\
\hline & 60 & 28 & 11.1 & 7.38 & 2.28 & 26 & 16.5 & 23.8 & 8.4 & 110 & 52 & 23 & & 23.7 & 3.19 & 245 & 312 & 11.2 & 8 & 352 & 7.59 \\
\hline \multirow{7}{*}{$\begin{array}{l}\text { t } \\
\text { U }\end{array}$} & 10 & 35.2 & 16 & 6.25 & 3.72 & 90 & 10.1 & 38.5 & 9.5 & 309 & 65 & & 4.73 & 2520 & 47.7 & 98 & 387 & 11.3 & 8.1 & 437 & 7.55 \\
\hline & 14 & 48.2 & 20.6 & 8.85 & 4.32 & 120 & 21.2 & 59.8 & 8.6 & 60 & 73 & & 2.14 & 44.9 & 2.98 & 86 & 519 & 11.1 & 8.9 & 418 & 7.89 \\
\hline & 19 & 48.9 & 19.8 & 8.81 & 4.48 & 124 & 22.3 & 59.3 & 7.88 & 42 & 67 & & 2 & 39.4 & 2.38 & 93 & 515 & 11.3 & 8.9 & 402 & 7.88 \\
\hline & 27 & 45 & 18.6 & 8.03 & 3.85 & 117 & 19.9 & 53.2 & 8.92 & 74 & 62 & & 1.89 & 83.2 & 3.11 & 124 & 488 & 11 & 8.3 & 408 & 7.74 \\
\hline & 35 & 36.1 & 12.8 & 9.14 & 2.27 & 29 & 32 & 44 & 10.1 & 108 & $<20$ & & 1.27 & 39.7 & 3.19 & 168 & 398 & 11 & 10.7 & 425 & 7.8 \\
\hline & 45 & 24.4 & 9.23 & 6.57 & 1.51 & 49 & 17.7 & 22.2 & 8.93 & 1300 & $<20$ & & 0.77 & 307 & 2.24 & 155 & 288 & 11 & 11.3 & 420 & 7.91 \\
\hline & 60 & 28 & 10.9 & 7.61 & 1.94 & 73 & 14.9 & 22.1 & 8.06 & 161 & 23 & & 1.27 & 41.3 & 1.95 & 247 & 309 & 11.1 & 9.8 & 401 & 7.71 \\
\hline
\end{tabular}

${ }^{1}$ Boron by ICP-OES, $\quad{ }^{2}$ Boron by ICP-MS 

urban water infrastructure in Bessacarr-Cantley

\begin{tabular}{|c|c|c|c|c|c|c|}
\hline \multirow{3}{*}{$\begin{array}{l}\text { Marker } \\
\text { species }\end{array}$} & \multicolumn{6}{|c|}{ Concentration range $\mathrm{mg} / \mathrm{l}$} \\
\hline & \multicolumn{4}{|c|}{ Bessacarr-Cantley study area } & \multicolumn{2}{|c|}{ Rural/periurban } \\
\hline & $\begin{array}{c}\text { Wastewater } \\
n=29\end{array}$ & $\begin{array}{c}\text { Mains supply } \\
\mathrm{n}=30-479 *\end{array}$ & $\begin{array}{c}\mathrm{M} / \text { levels } 0-30 \mathrm{~m} \\
\mathrm{n}=75\end{array}$ & $\begin{array}{c}\mathrm{M} / \text { levels } 30- \\
60 \mathrm{~m} \mathrm{n}=65\end{array}$ & 8 private wells $n=30$ & $\begin{array}{c}3 \text { public supplies } \\
n=30-410\end{array}$ \\
\hline $\mathrm{Cl}^{-}$ & $60-90$ & $26-41$ & $10-170$ & $15-110$ & $15-90$ & $20-80$ \\
\hline $\mathrm{SO}_{4}^{-}$ & $60-100$ & $27-46$ & $30-140$ & $20-160$ & $20-350$ & $30-80$ \\
\hline $\mathrm{HCO}_{3}^{-}$ & $400-575$ & $180-240$ & $90-300$ & $35-275$ & $100-550$ & $100-220$ \\
\hline $\mathrm{K}$ & $17.5-22.5$ & $2-3$ & $1.5-13$ & $1.5-6.5$ & $2-28$ & $2.5-3.5$ \\
\hline B & $0.15-0.5$ & $\mathrm{Bdl}(0.05)$ & $0.04-0.14$ & $0.01-.09$ & $0.025-0.1$ & $<0.1$ \\
\hline $\mathrm{NH}_{4}-\mathrm{N}^{-}$ & $25-75$ & $<.02$ & & & $<0.01-0.5$ & $<0.02$ \\
\hline $\mathrm{NO}_{2}-\mathrm{N}^{--}$ & $0.01-2.5$ & $0.003-0.02$ & $<0.001-0.03$ & $<0.001-.0 .03$ & $<0.001-0.14$ & $<0.001-0.08$ \\
\hline TON & $<2$ & $0.5-10$ & $2.5-13.5$ & $5-17$ & $<0.1-30$ & $5-16$ \\
\hline DOC & $30-110$ & N/A & $1-5$ & $0.7-2$ & $1.5-7$ & N/A \\
\hline Data source & FS & YW & FS & FS & FS & FS \\
\hline
\end{tabular}

Bdl

Wastewater:

Mains supply:

Multilevels:

Private wells:

Public supplies:

FS

YW

TON

DOC
Depending on parameter measured

below detection level

3 sites: Burnham Close, Everingham Rd, Warning Tongue Lane

Nutwell combined raw (blend of Armthorpe, Boston Park, Nuwell, Thornham PS waters)

5 sites: Haslam Park 1 \& 2, Bolton Hill, McAuley School, Sandall Beat

8 sites (Beechtree Nurseries, Doncaster Racecourse, Gatewood Grange, Misson Quarry, Warning Tongue Lane, , Elmstone, Crowtree and Lings Farms)

3 sites (Nutwell, Rossington Bridge and Armthorpe pumping stations, various b/hs)

Data collected by AISUWRS project team Jun 2003 - Nov 2004

Data from Yorkshire Water raw water quality surveillance archive Jan 1999 - Mar 2004

Total oxidised nitrogen, a laboratory measurement representing sample nitrate and nitrite concentrations; nitrate is the main constituent as all of the groundwaters were aerobic and nitrite concentrations were generally $<0.1 \mathrm{mg} / 1 \mathrm{NO}-\mathrm{N}_{2}$

Dissolved organic carbon 
Faecal indicator sampling Jul 2003 - Nov 2004 (modified from Cronin et al. 2005); results expressed as percentage positives

\begin{tabular}{lccc}
\hline & $\begin{array}{c}\text { Multilevel } \\
\text { depth- } \\
\text { specific } \\
\text { intervals } \\
\mathrm{n}=154\end{array}$ & $\begin{array}{c}\text { Regional } \\
\text { well } \mathrm{n}=45\end{array}$ & Sewers $\mathrm{n}=43$ \\
\hline Field Thermotolerant coliforms TTC \% & 18 & 11 & \\
E. coli \% & 18 & 16 & 100 \\
Total coliforms \% & 34 & 24 & 100 \\
Faecal streptococci FS. \% & 40 & 24 & 100 \\
Sulphite-reducing clostridia SRC \% & 44 & 47 & 100 \\
Coliphage $\%$ & 1 & 7 & 100 \\
\hline & $\mathrm{n}=60$ & $\mathrm{n}=3$ & $\mathrm{n}=17$ \\
Enteric virus ${ }^{2} \%$ & 12 & 0 & 100 \\
\hline
\end{tabular}

${ }^{1}$ Analyses of thermotolerant coliforms were undertaken in the field using a portable DelAgua testing kit as well as samples being sent for laboratory filtration and confirmation (shown in the next row named E. coli), ${ }^{2}$ Combination of results from two methods 
Faecal streptococci survivability comparison

\begin{tabular}{lcc}
\hline & Upper range & Lower range \\
\hline Concentration in Sewer* & $10^{5}$ & $10^{6}$ \\
Half-life (days) & $1.925^{* *}$ & $3.008^{* * *}$ \\
Time to decay to $<10^{1}$ (days) & 27.0 & 51.1 \\
\hline
\end{tabular}

* $\quad$ Sewer sampling July 2003 - November 2004, 6 sampling campaigns

** from Yates et al. 1985

*** from Keswick et al. 1982 
List of Figures

Figure $1 \quad$ Location of Doncaster and Bessacarr-Cantley study area on Permo-Triassic sandstone aquifer

Figure 2 Urban water infrastructure of Bessacarr-Cantley study area and sampling locations

Figure 3 Sketch section across Sherwood Sandstone aquifer in vicinity of Doncaster.

Figure 4 Figure 4 Piezometric variation in HP2 multilevel. L10, L14 etc= depth of sampling port. For comparative purposes the piezometric level in L10 (which fluctuated $0.28 \mathrm{~m}$ over period) has been normalised. Note synchronicity of variation at all ports down to $60 \mathrm{mbgl}$ and small magnitude of relative head difference

Figure 5 Average atmospheric mixing ratios over time of the CFCs and $\mathrm{SF}_{6}$ in pptv (parts per trillion by volume), and corresponding groundwater concentrations at a recharge temperature of $10^{\circ} \mathrm{C}$. Mixing ratio data from the NOAA (US National Oceanic and Atmospheric Administration).

Figure 6 Design of 5 multilevel research boreholes, Bessacarr-Cantley; thick lines indicate steel casing, dark areas the location of bentonite seals, numbers in bold the depths $0.3 \mathrm{~m}$ long sampling port centres (from Rueedi and Cronin 2003).

Figure 7A CFC-12 vs $\mathrm{SF}_{6}$ concentrations - all samples. Dashed lines represent water in equilibrium with average 2004 atmospheric concentrations

Figure 7B CFC-11 vs $\mathrm{SF}_{6}$ concentrations, subset of samples showing low or no enrichment from local CFC sources

Figure $8 \quad \mathrm{CFC}, \mathrm{SF}_{6}$ depth plots in MF form

Figure 9 Crossplot of CFC-11 vs CFC-12 for multilevel sites.

Figure 10 Crossplot of CFC-11 vs CFC-12 for private wells and public supply boreholes in the vicinity of Bessacarr-Cantley

Figure $11 \quad$ Urban recharge inorganic indicator profiles for HP2, October 2003-September 2004

Figure 12 Microbial indicator depth profiles in HP2 multilevel Jul 2003-Sept 2004; 68\% of SRC and 57\% of FS samples gave positive counts

Figure 13 Conceptual model of flow system in Sherwood Sandstone in general vicinity of Bessacarr-Cantley suburb of Doncaster 


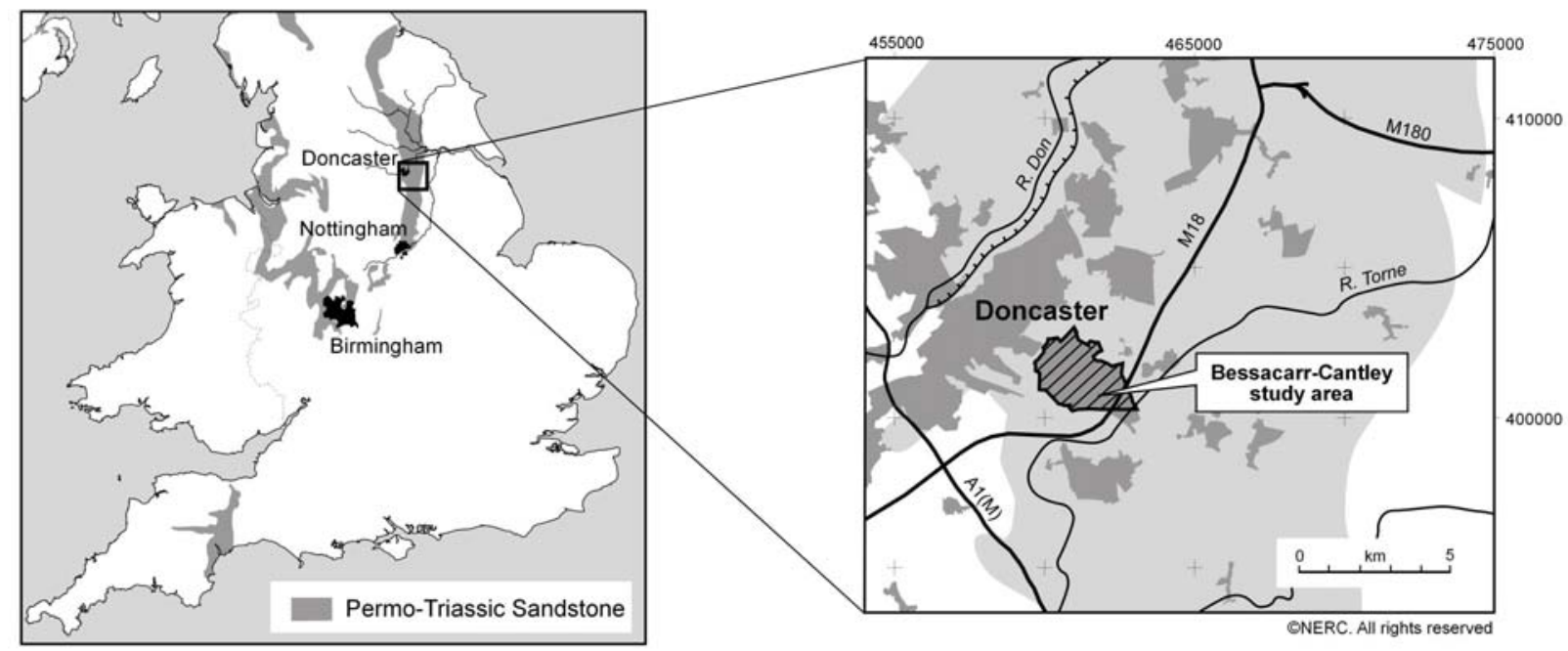

Figure 1 Location of Doncaster and Bessacarr-Cantley study area on Permo-Triassic sandstone aquifer

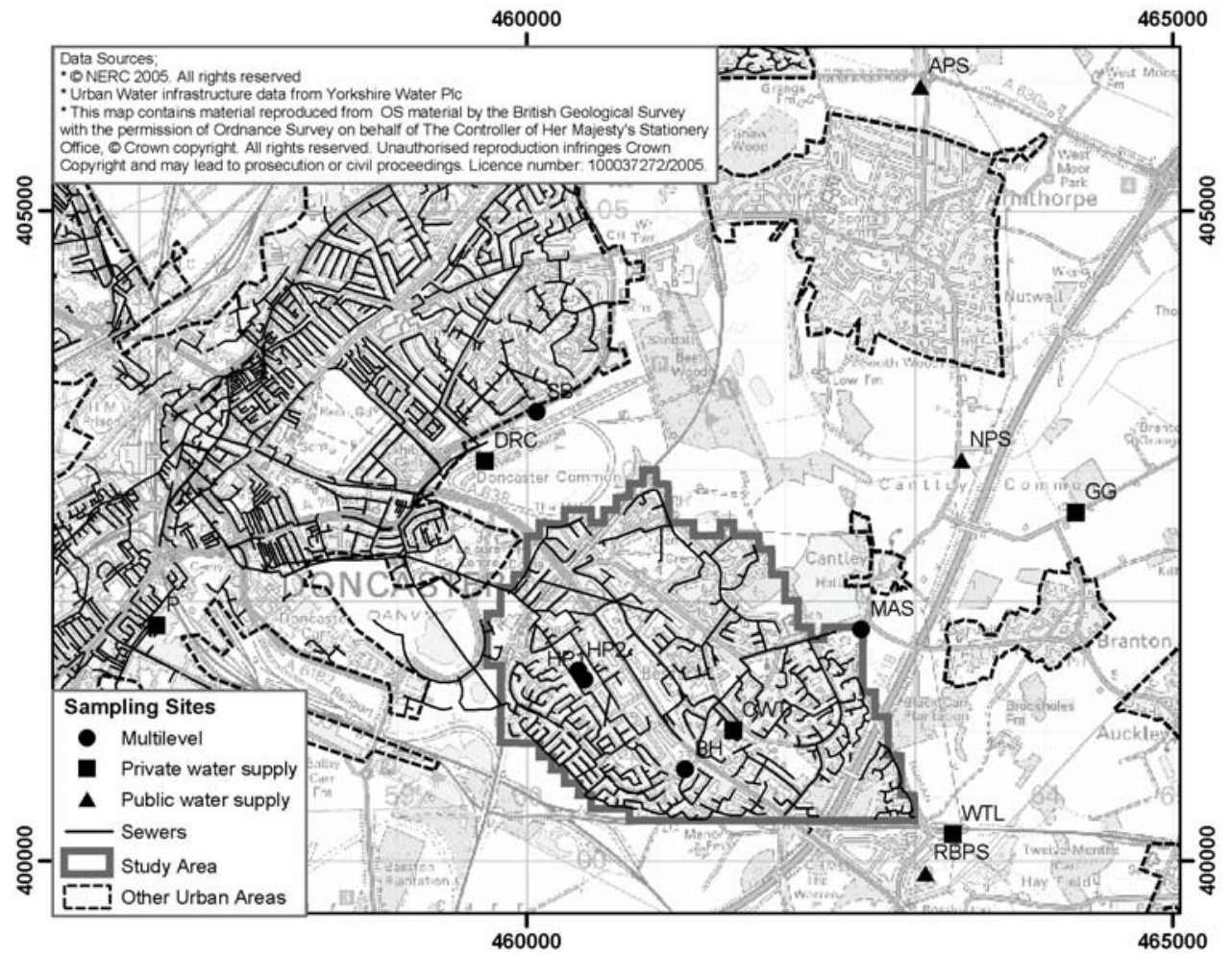

Figure 2 Urban water infrastructure of Bessacarr-Cantley study area and sampling locations 


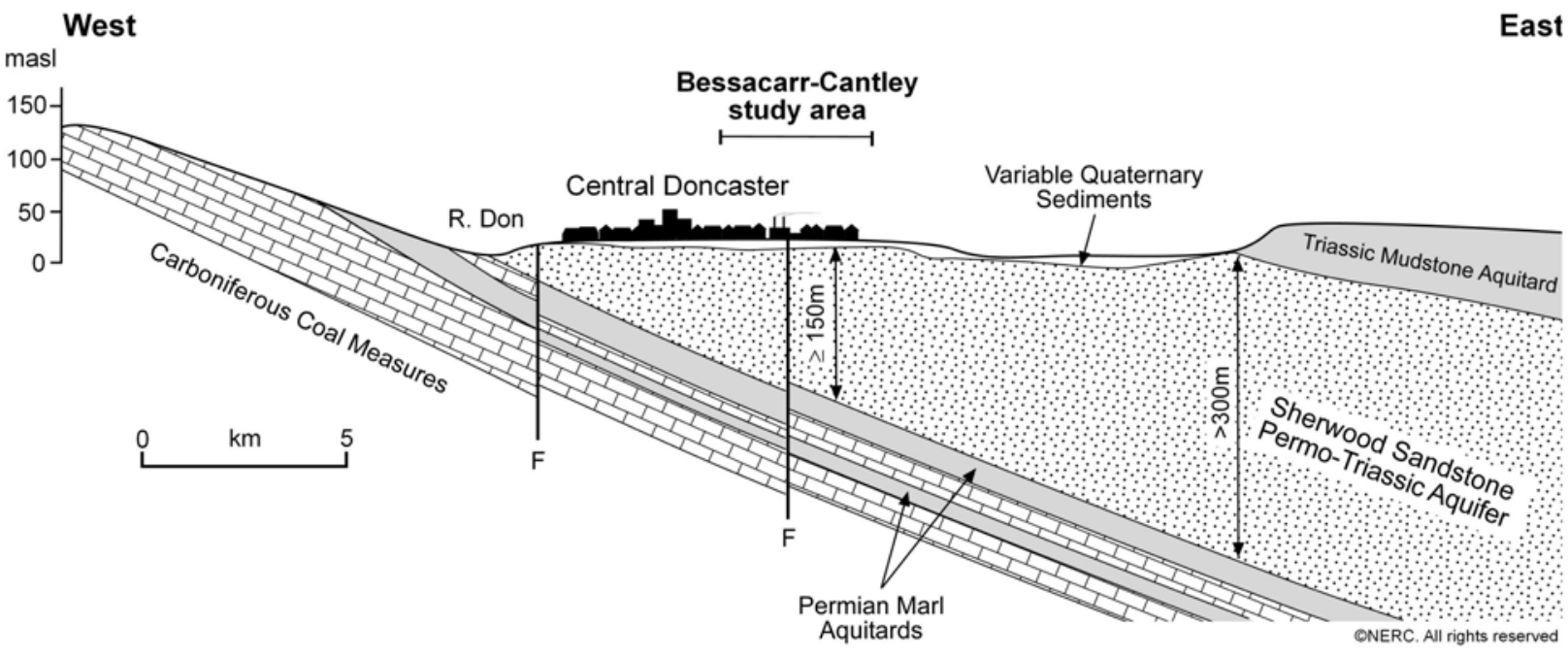

Figure 3 Sketch section across Sherwood Sandstone aquifer in vicinity of Doncaster.

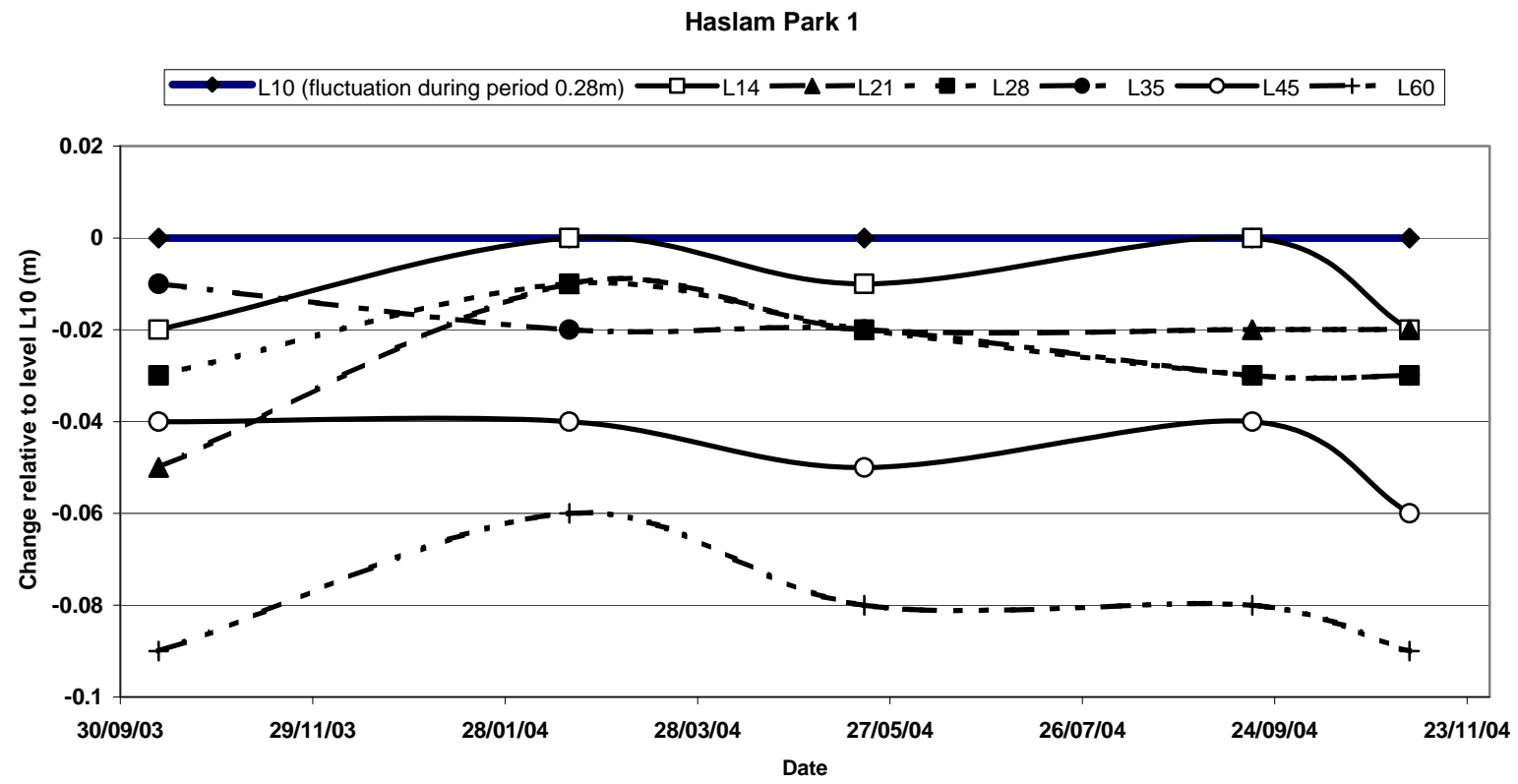

Figure 4 Piezometric variation in HP2 multilevel. L10, L14 etc= depth of sampling port. For comparative purposes the piezometric level in L10 (which fluctuated $0.28 \mathrm{~m}$ over period) has been normalised. Note synchronicity of variation at all ports down to $60 \mathrm{mbgl}$ and small magnitude of relative head difference 

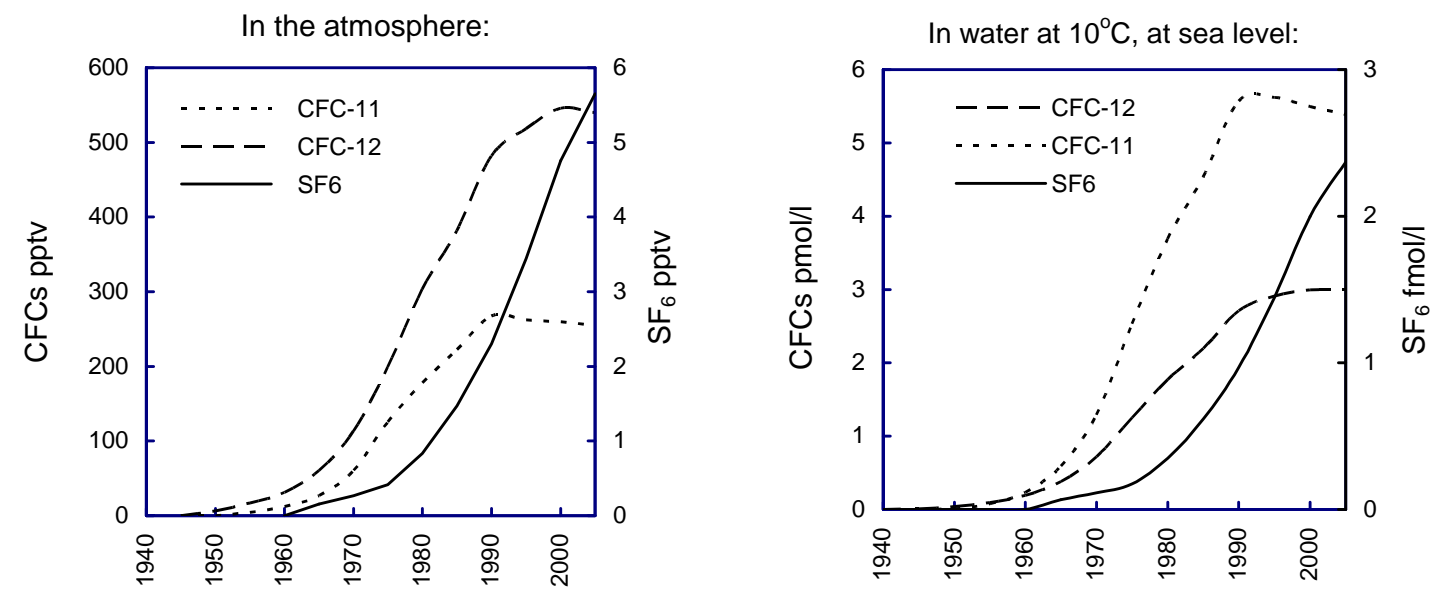

Fig 5 Average atmospheric mixing ratios over time of the CFCs and $\mathrm{SF}_{6}$ in pptv (parts per trillion by volume), and corresponding groundwater concentrations at a recharge temperature of $10^{\circ} \mathrm{C}$. Mixing ratio data from the NOAA (US National Oceanic and Atmospheric Administration). 


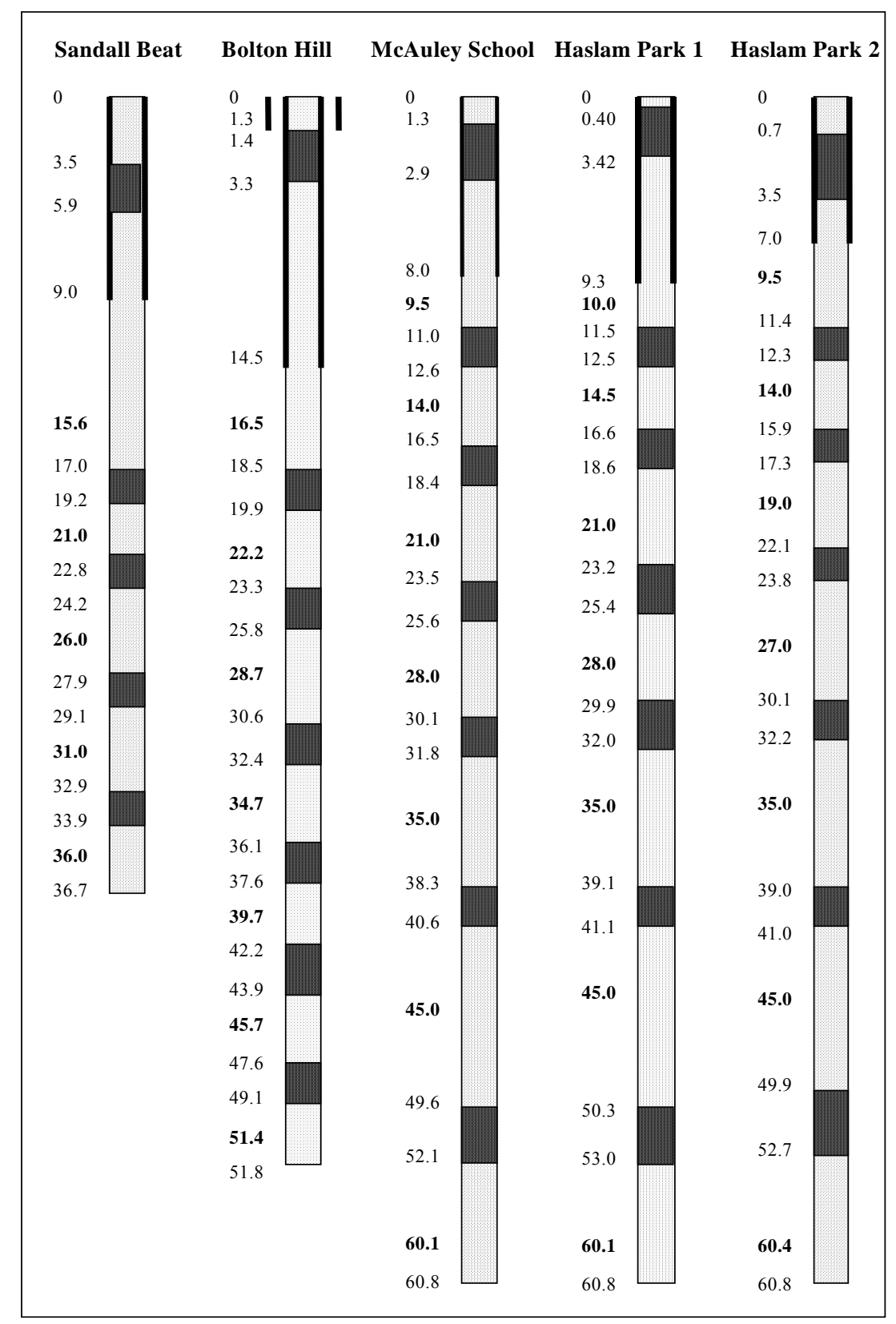

Figure 6 Design of 5 multilevel research boreholes, Bessacarr-Cantley; thick lines indicate steel casing, dark areas the location of bentonite seals, numbers in bold the depths of the centre of the $0.3 \mathrm{~m}$ long sampling port (from Rueedi and Cronin 2003). 


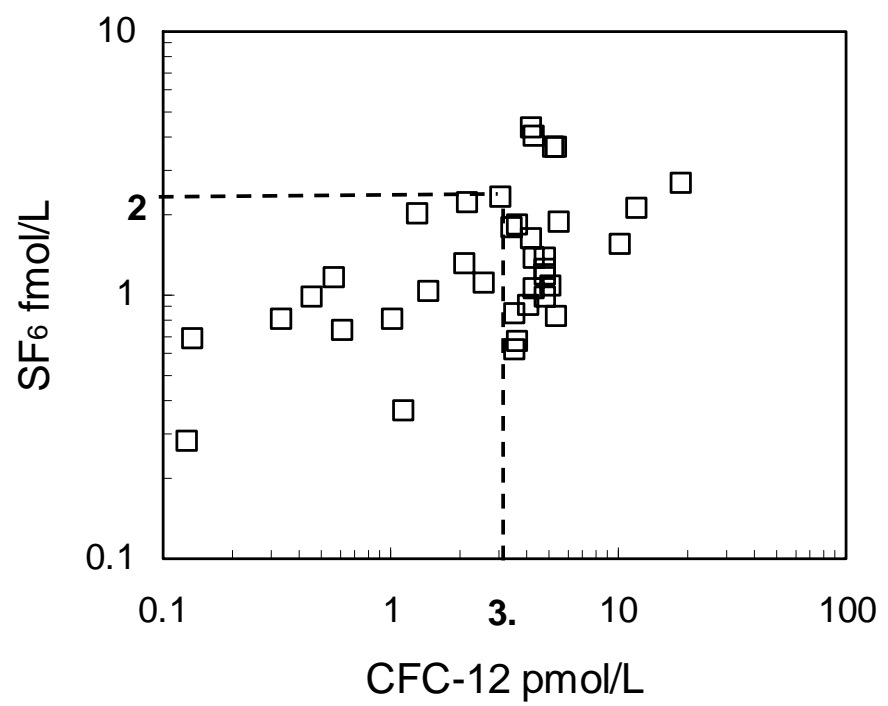

Figure 7A CFC-12 vs $\mathrm{SF}_{6}$ concentrations - all samples. Dashed lines represent water in equilibrium with average 2004 atmospheric concentrations

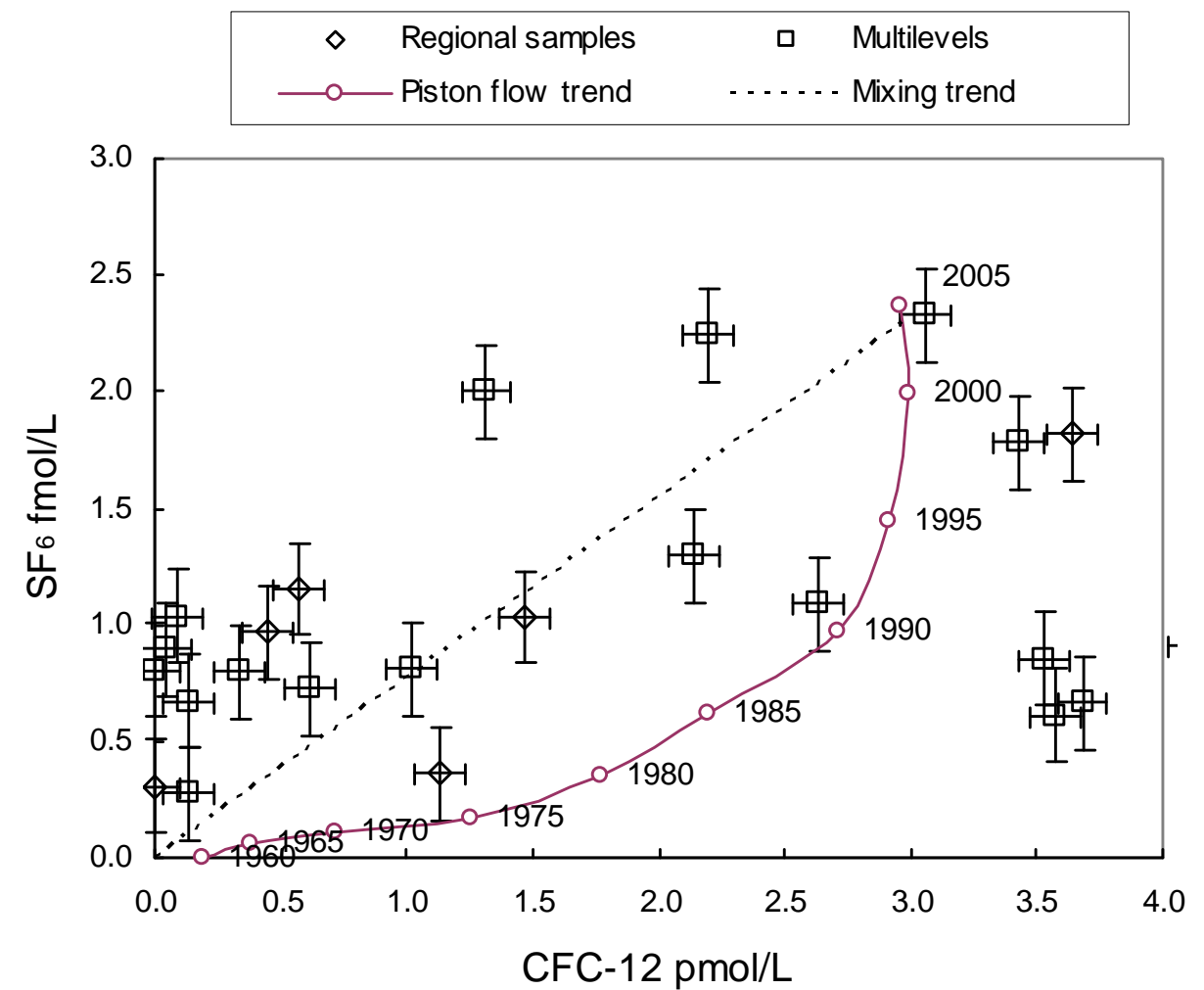

Figure 7B CFC-11 vs $\mathrm{SF}_{6}$ concentrations, subset of samples showing low or no enrichment from local CFC sources 


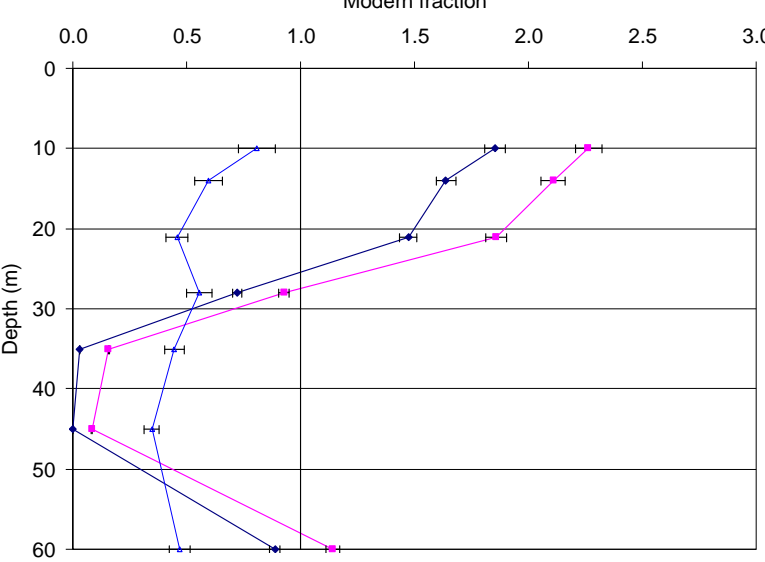
Modern fraction

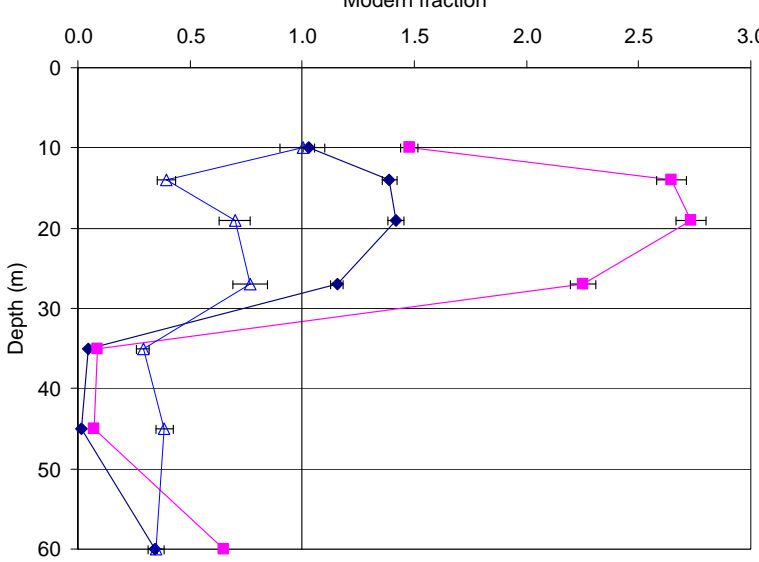

Bolton Hill M/L

McAuley High School M/L

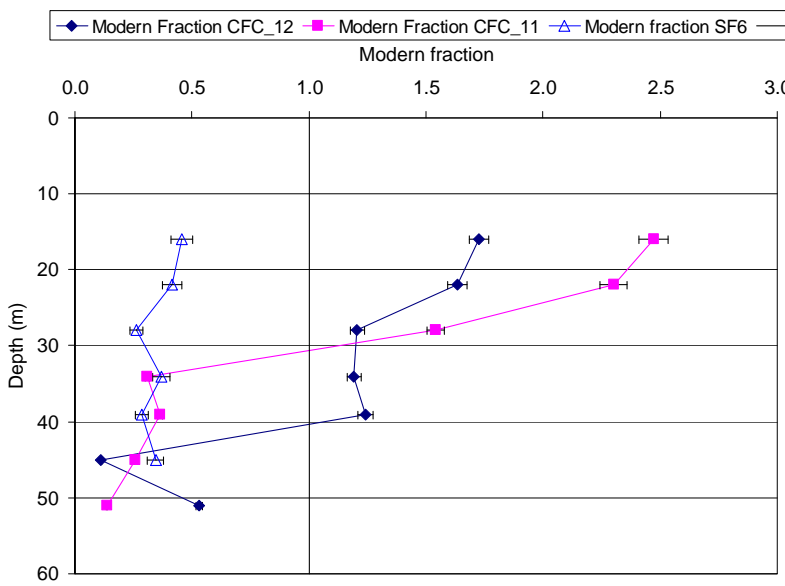

- Modern Fraction CFC_12 - Modern Fraction CFC_11 $\triangle$ Modern fraction SF6 -
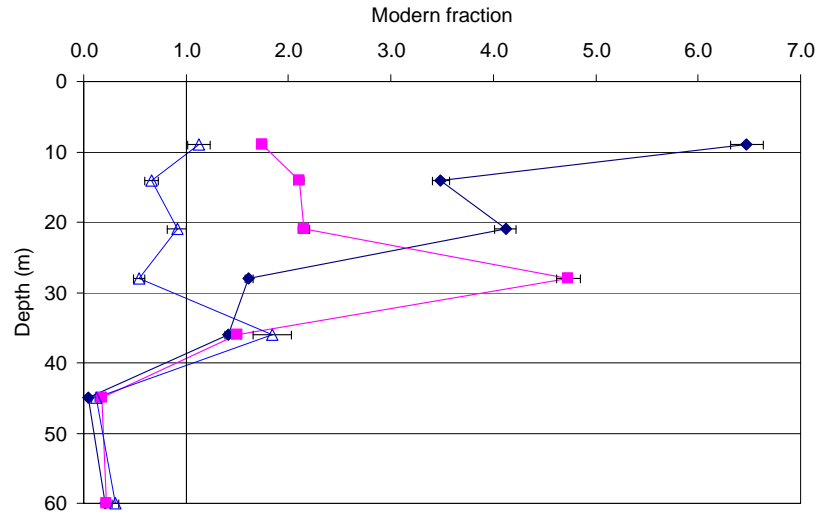

Sandall Beat M/L

- Modern Fraction CFC_12 - - Modern Fraction CFC_11 $\triangle$ Modern fraction SF6 -

Modern fraction

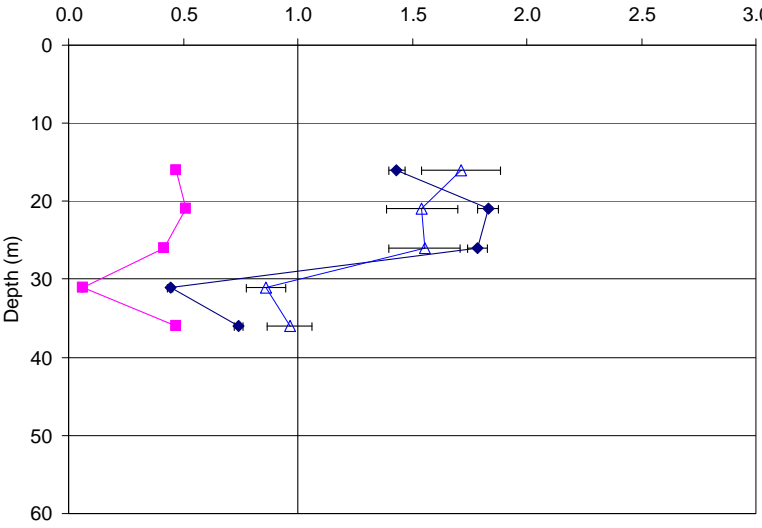

Figure $8 \mathrm{CFC}, \mathrm{SF}_{6}$ depth plots in 'modern fraction' form: a value of $>1$ signifies a local source additional to average atmospheric ratios 
- Multilevels HP1, HP2

A 2005 Atmospheric equilibrium concn @10 $\mathrm{C}$ - Linear (Multilevels BH, SB, MAS)

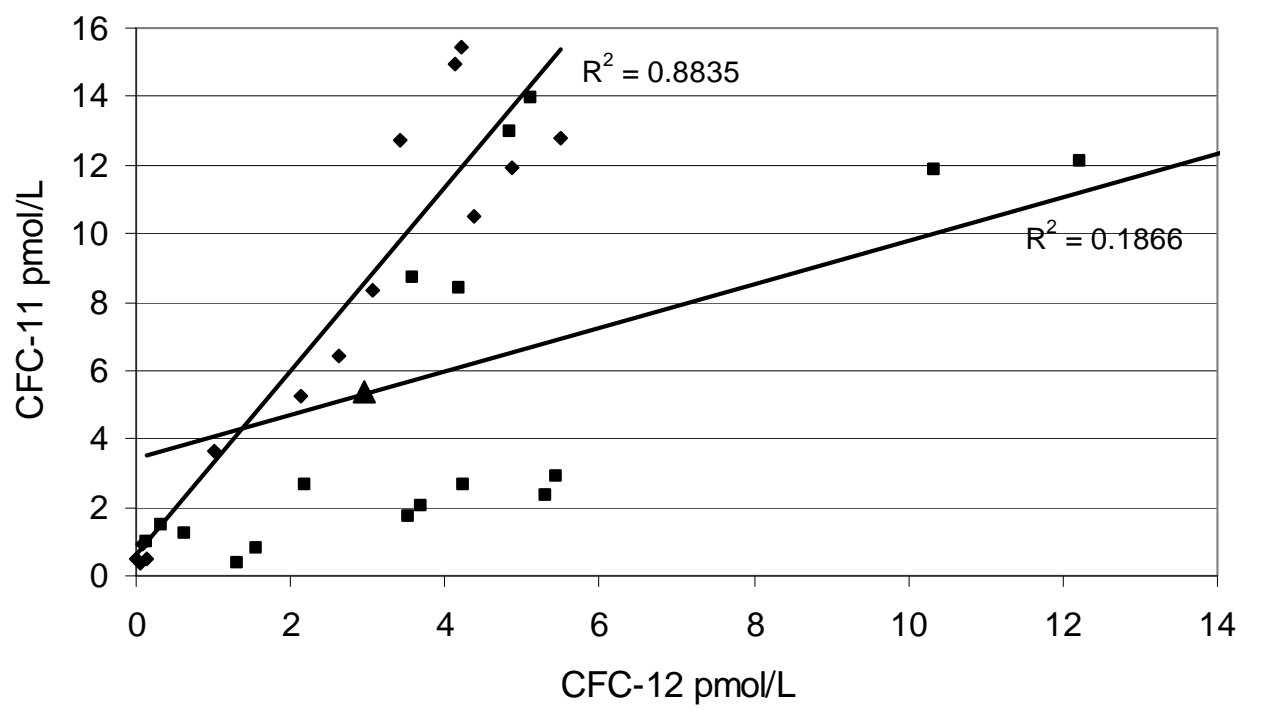

- Multilevels BH, SB, MAS

_ Linear (Multilevels HP1, HP2)

Figure 9 Crossplot of CFC-11 vs CFC-12 for multilevel sites.

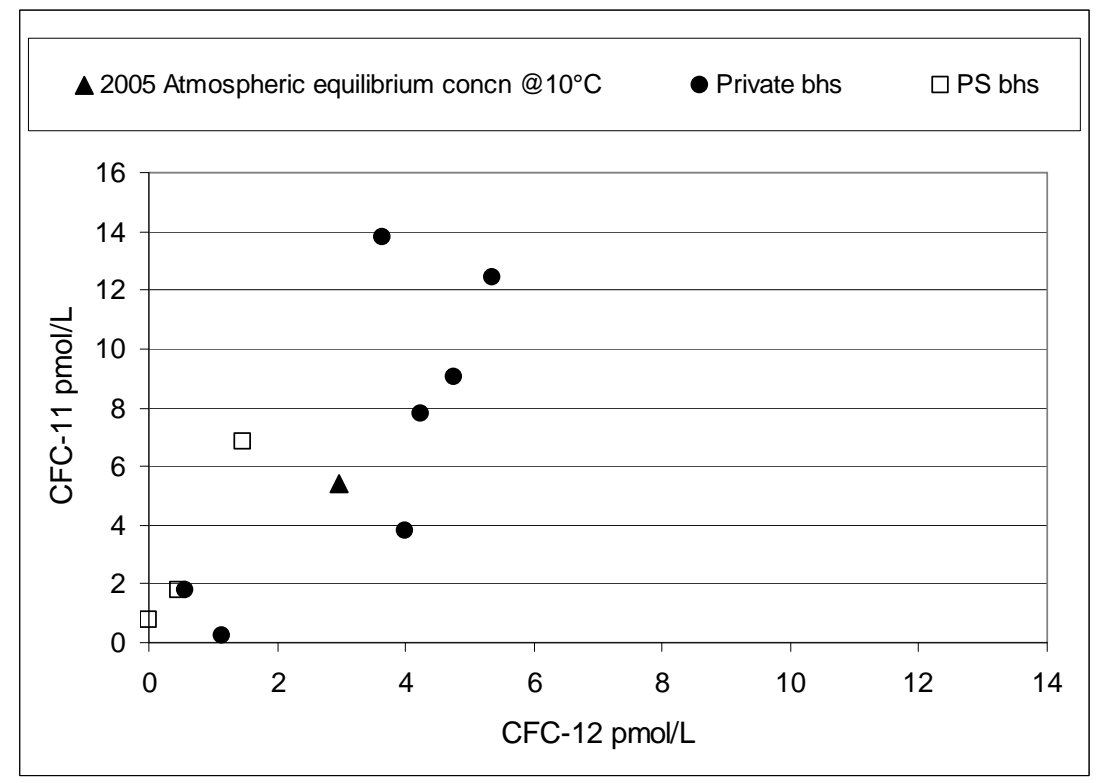

Figure 10

Crossplot of CFC-11 vs CFC-12 for private wells and public supply boreholes in the vicinity of Bessacarr-Cantley 

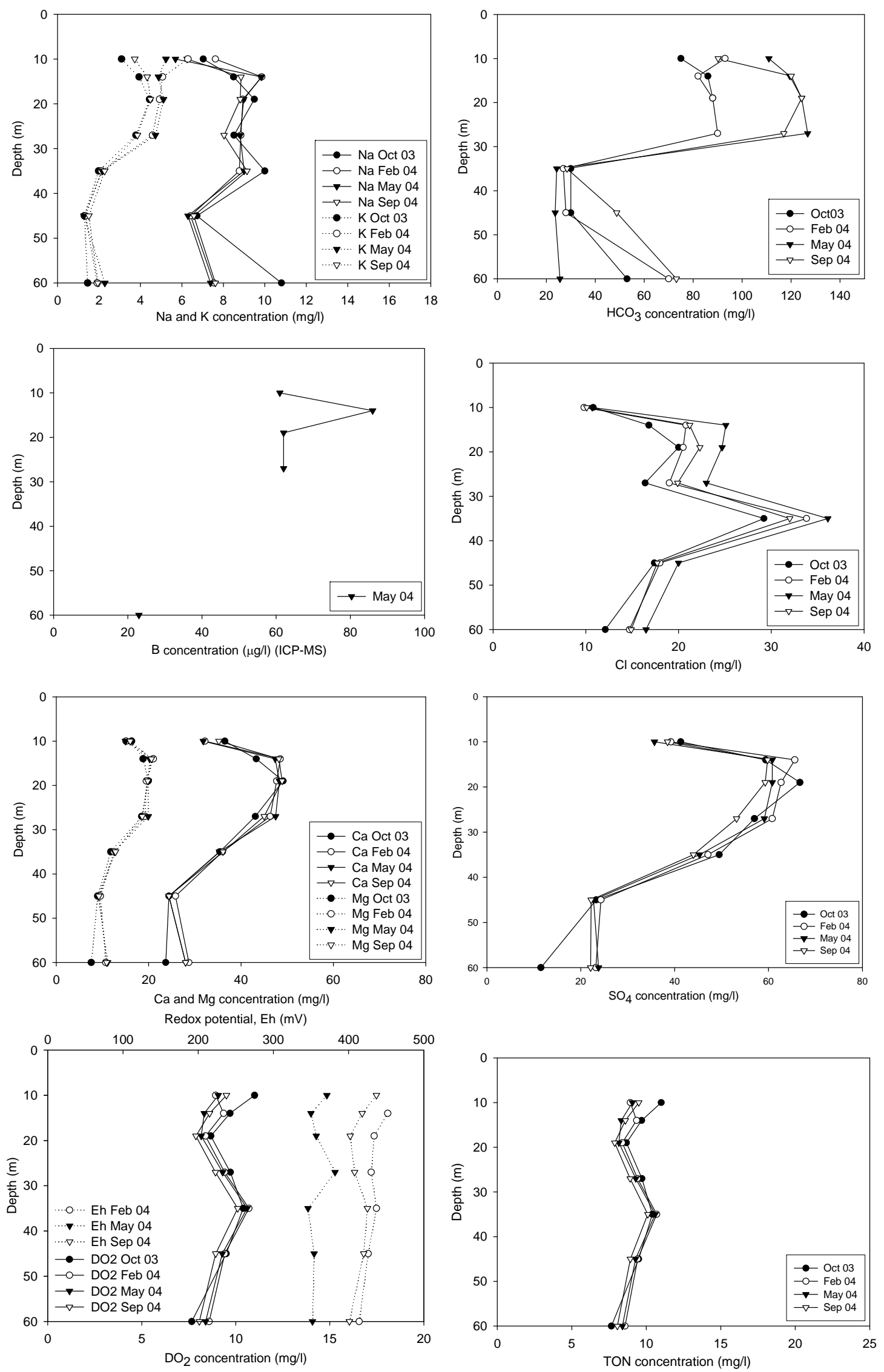

Figure 11 Urban recharge inorganic indicator profiles for HP2, October 2003-September 2004 

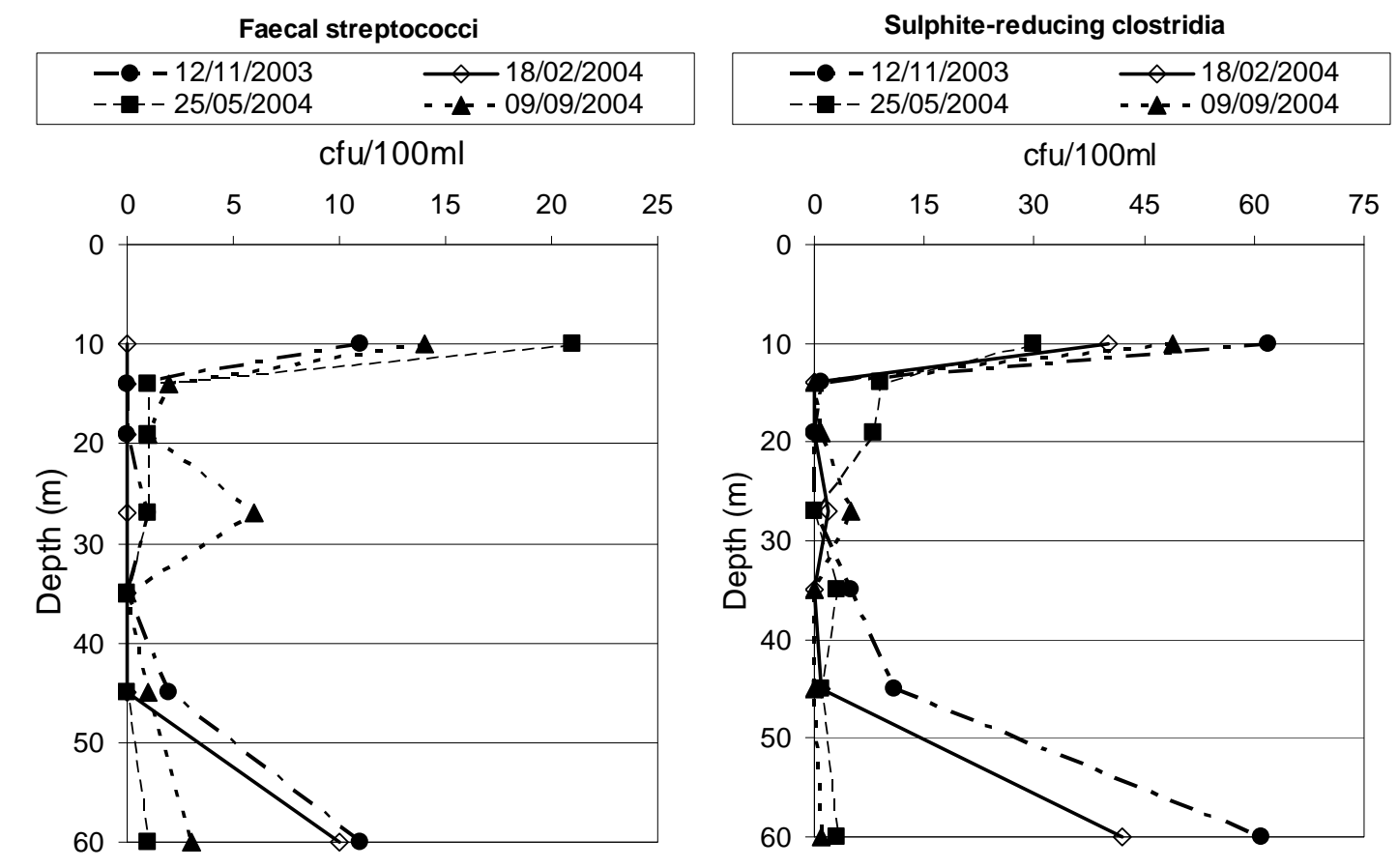

Figure 12 Microbial indicator depth profiles in HP2 multilevel Jul 2003-Sept 2004; 68\% of SRC and 57\% of FS samples gave positive counts 


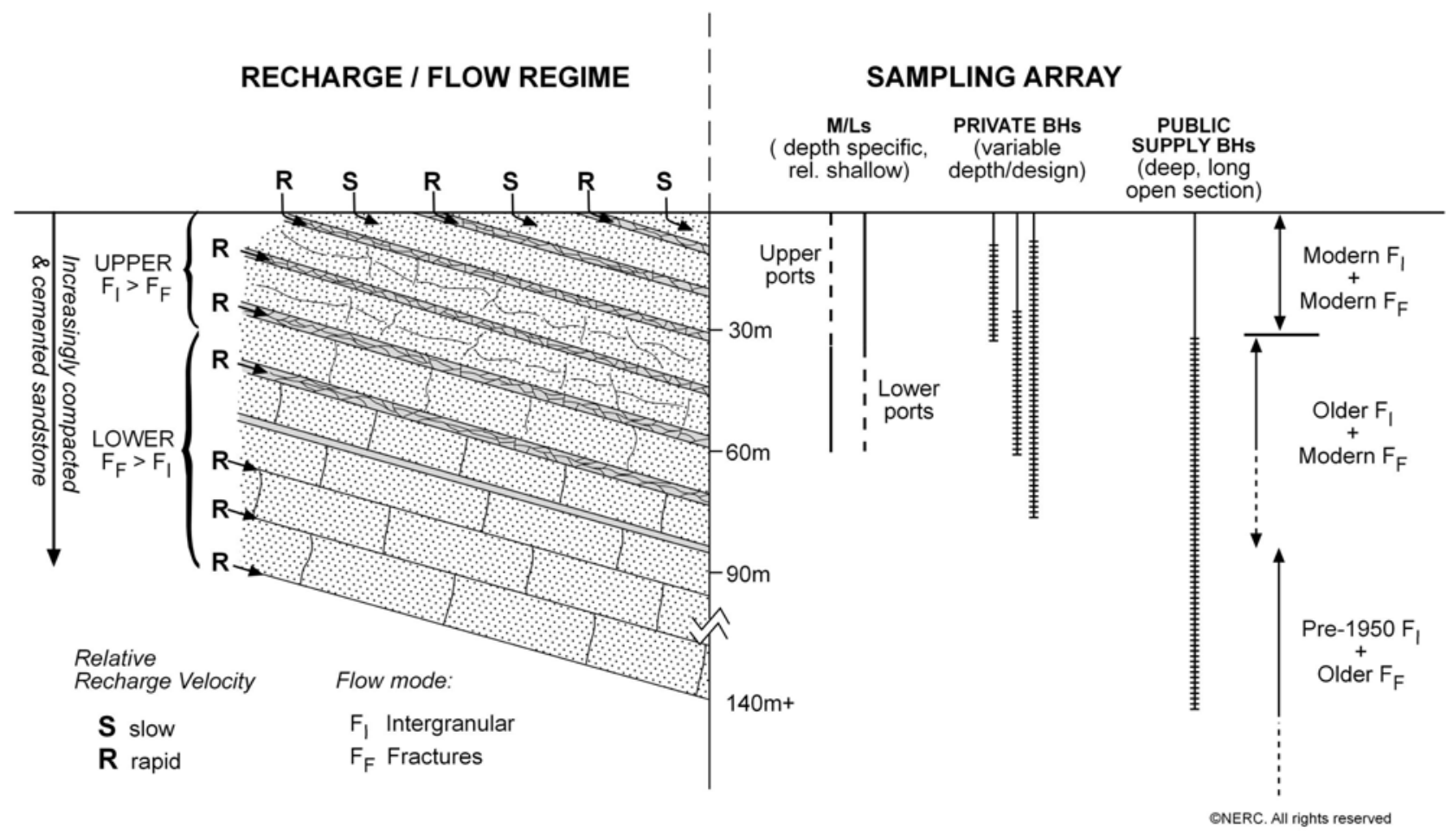

Figure 13 Conceptual model of flow system in Sherwood Sandstone in general vicinity of Bessacarr-Cantley suburb of Doncaster 